\title{
Intersections of Jane Jacobs' conditions for diversity and low-carbon urban systems: a look at four global cities
}

Article

Accepted Version

Mohareb, E., Derrible, S. and Peiravian, F. (2016) Intersections of Jane Jacobs' conditions for diversity and lowcarbon urban systems: a look at four global cities. Journal of Urban Planning and Development, 142 (2). 05015004. ISSN 1943-5444 doi: https://doi.org/10.1061/(ASCE)UP.19435444.0000287 Available at https://centaur.reading.ac.uk/44980/

It is advisable to refer to the publisher's version if you intend to cite from the work. See Guidance on citing.

Published version at: http://ascelibrary.org/doi/abs/10.1061/\%28ASCE\%29UP. 1943-5444.0000287 To link to this article DOI: http://dx.doi.org/10.1061/(ASCE)UP.19435444.0000287

Publisher: American Society of Civil Engineers

All outputs in CentAUR are protected by Intellectual Property Rights law, including copyright law. Copyright and IPR is retained by the creators or other copyright holders. Terms and conditions for use of this material are defined in the End User Agreement. 


\section{CentAUR}

Central Archive at the University of Reading

Reading's research outputs online 
Please Cite as: Mohareb, E., Derrible, S., and Peiravian, F. (2015). "Intersections of Jane Jacobs' Conditions for Diversity and Low-Carbon Urban Systems: A Look at Four Global Cities." J. Urban Plann. Dev. , 10.1061/(ASCE)UP.1943-5444.0000287 , 05015004.

\title{
Intersections of Jane Jacobs' Conditions for Diversity and Low-Carbon Urban Systems: A Look at Four Global Cities
}

\author{
Eugene Mohareb $^{1}$, Sybil Derrible $^{2}$, Farideddin Peiravian $^{3}$
}

Keywords: Jane Jacobs, diversity, urban sustainability, greenhouse gases, population, urban form, transportation, infrastructure, climate

\footnotetext{
${ }^{1}$ Corresponding author; eugene.mohareb@alum.utoronto.ca, Post-Doctoral Fellow, Centre for Sustainable Development, Engineering Department, Cambridge University, Trumpington Street, Cambridge CB2 1PZ, United Kingdom $^{2}$ derrible@ uic.edu, Assistant Professor, Civil Engineering Department, University of Illinois at Chicago, Chicago, IL, 60657, USA ${ }^{3}$ fpeira2@uic.edu, Research Associate, Civil Engineering Department, University of Illinois at Chicago, Chicago, IL, 60657, USA
} 


\begin{abstract}
Countless cities are rapidly developing across the globe, pressing the need for clear urban planning and design recommendations geared towards sustainability. This article examines the intersections of Jane Jacobs' four conditions for diversity with low-carbon and low-energy use urban systems in four cities around the world: Lyon (France), Chicago (United-States), Kolkata (India), and Singapore (Singapore). After reviewing Jacobs' four conditions for diversity, we introduce the four cities and describe their historical development context. We then present a framework to study the cities along three dimensions: population and density, infrastructure development/use, and climate and landscape. These cities differ in many respects and their analysis is instructive for many other cities around the globe. Jacobs' conditions are present in all of them, manifested in different ways and to varying degrees. Overall we find that the adoption of Jacobs' conditions seems to align well with concepts of low-carbon urban systems, with their focus on walkability, transit-oriented design, and more efficient land use (i.e., smaller unit sizes). Transportation sector emissions seems to demonstrate a stronger influence from the presence of Jacobs' conditions, while the link was less pronounced in the building sector. Kolkata, a low-income, developing world city, seems to possess many of Jacobs' conditions, while exhibiting low per capita emissions - maintaining both of these during its economic expansion will take careful consideration. Greenhouse gas mitigation, however, is inherently an in situ problem and the first task must therefore be to gain local knowledge of an area before developing strategies to lower its carbon footprint.
\end{abstract}


Please Cite as: Mohareb, E., Derrible, S., and Peiravian, F. (2015). "Intersections of Jane Jacobs' Conditions for Diversity and Low-Carbon Urban Systems: A Look at Four Global Cities." J. Urban Plann. Dev. , 10.1061/(ASCE)UP.1943-5444.0000287 , 05015004.

\section{Introduction}

Although it was written more than 50 years ago, Jane Jacobs' seminal work, "The Death and Life of Great American Cities" (Jacobs, 1961), remains an insightful and important text to this day. Jacobs is seen as one of the key proponents of shifting away from modern urban form. Indeed, she was a staunch critic of master planning, suburban expansion, and single-use planning schemes, which had been pioneered by Ebenezer Howard and Le Corbusier and championed to varying degrees by a number of influential 20th century designers including Lewis Mumford and Frank Lloyd Wright (Jacobs, 1961; Breheny, 1996). Jacobs opposition to these approaches stemmed from her view that cities are self-organizing complex systems and should be encouraged to develop according to micro-scale social and market forces. The current shift towards more compact, walkable, transit-oriented, and mixed-use developments suggests that urban decision makers have accepted her (and her like-minded contemporaries') theories on urban growth and decay.

A great deal of overlap exists between prominent notions of urban sustainability and Jacobs' ideas for creating vibrant cities. For example, in the development of Litman's (2014) indicators for sustainable transportation, planning objectives such as land use mix, walkability/bikeability, and quality of road/street environments appear alongside per capita transport energy consumption and transportation emissions (nitrogen oxides, volatile organic compounds, particulate matter, etc). Moreover, current notions of how to reduce energy demand and mitigate greenhouse gas (GHG) emissions also align with Jacobs' ideas of a diverse and economically successful urban area (Seto et al. 2014; Otkay, 2012; Kennedy, 2011; Talen, 2011; Jabareen, 2006). Indeed some quantitative analysis has been conducted in this regard; for example, Ewing et al (2013) found that mixed-use developments built to LEED-ND (Leadership in Energy and Environmental Design - New Development) standards have been estimated to reduce per capita vehiclekilometers traveled (VKT) by 24-60\%. Porter (2009) suggests that a $12 \%$ reduction in national transportation-related GHGs through aggressive implementation of compact land use approaches (i.e., transit-oriented development). In addition to the GHG savings, considerable cost savings can be associated with these types of approaches, with Mashayekh et al. (2011) suggesting that compact, mixed-use brownfield development save residents $\$ 3,500$ - 4,000 USD per year in driving time, fuel, and external air pollution.

Established cities face substantial challenges in reducing their GHG emissions, with current projections for low-carbon technology adoption being insufficient to meet longterm mitigation targets (Mohareb and Kennedy 2014). This inherently suggests that behavior (i.e., energy demand reduction) approaches to mitigation are also important, many of which are underpinned by changes in urban form and spatial planning (Seto et al. 2014). In this article, we restrict our analysis of urban sustainability to this important issue of low-carbon urban systems. There is a strong correlation between energy demand and GHG emissions, since fossil fuels provided an estimated $86 \%$ of energy demand 
Please Cite as: Mohareb, E., Derrible, S., and Peiravian, F. (2015). "Intersections of Jane Jacobs' Conditions for Diversity and Low-Carbon Urban Systems: A Look at Four Global Cities." J. Urban Plann. Dev. , 10.1061/(ASCE)UP.1943-5444.0000287 , 05015004.

within cities in 2006 (IEA, 2008; see Table 8.2, p.183). As a result, urban GHGs and urban energy use are henceforth used interchangeably in the context of their quantification and mitigation. For this work, we argue that Jacobs' ideas represent a means/process, in the form of planning objectives, to achieving reductions in urban GHG emissions. Central to Jacobs' conception of what makes a functional, vibrant city, are the four "conditions for diversity" (these will henceforth be referred to as "Jacobs' conditions", as a shorthand), which we will review later.

Jacobs' conditions, however, are not universal in their application, and as we will see, are manifested in many different ways. It follows that dealing with urban GHG mitigation is inherently an in situ problem (i.e., context-sensitive), requiring tailored solutions for each city; approaches to reduce GHG emissions in Chicago (US) would not necessarily work in Kolkata (India). Analyzing the commonalities between low-energy/low-carbon cities on the one hand, and vibrant and diverse cities on the other hand is paramount, as countless cities from emerging countries are rapidly expanding and are faced with the challenge of developing in a way that both enhances economic prosperity while keeping adverse environmental and social impacts low.

In this article, we look at the profiles of four cities worldwide that vary vastly in their urban development, and that either have benefited or can benefit from adapting or nurturing Jacobs' conditions. These cities are Lyon (France), Chicago (United States), Kolkata (India), and Singapore (Singapore). They are selected because they developed in different eras and under different conditions (economic, climatic, and political), which has resulted in unique urban forms and varying degrees of adherence to Jacobs' four conditions. The breadth of comparison provided through the selection of these differing urban contexts provides insight into individual cities' unique challenges in mitigating their climate impacts, as well as the different ways Jacobs' conditions are exhibited. Given the differing positions in their stage of development and the history of their growth, the challenges these cities face in reducing GHG emissions can be instructive to a broader urban audience when considered together. Moreover, the authors have personally lived in these four cities, which enables us to discuss certain features that can be hard to measure (although our focus is primarily on quantitative analysis).

The article is structured as follows. First, Jacobs' conditions for diversity are reviewed. Second, the four cities are introduced, and their individual histories are discussed. Third, the framework for comparing four world cities against Jacobs' conditions is detailed, which is based on three dimensions: Population and Density, Infrastructure Development/Use, Climate and Landscape. Finally, a discussion of the perceived intersection of Jacobs' conditions and low-carbon cities is presented. Through the comparison of the four urban profiles, the purpose of this paper is to relate Jacobs' conditions with urban GHG mitigation and determine how cities can further learn from Jacobs' conditions to substantially deviate from a development path that exacerbates climate change. 
Please Cite as: Mohareb, E., Derrible, S., and Peiravian, F. (2015). "Intersections of Jane Jacobs' Conditions for Diversity and Low-Carbon Urban Systems: A Look at Four Global Cities." J. Urban Plann. Dev. , 10.1061/(ASCE)UP.1943-5444.0000287 , 05015004.

\section{Jane Jacobs' Four Conditions of Diversity}

Central to Jacobs' (1961) description of what makes a city (or its component neighborhoods) successful is an "intricate and close-grained diversity of uses that give each other constant mutual support" (p.14). Essentially, a well-functioning urban space allows continual opportunities for a variety of different uses and types of interactions; this provides it with safety ("eyes on the street"), economic activity, and general vibrancy throughout the day. Jacobs' work embraces urban complexity, which is groundbreaking, as it demonstrates that urban planning provides an application for what was a new science at the time. In order for a city to be sufficiently diverse (and its function sufficiently complex), four conditions of diversity must be present:

1. Multiple uses, encouraging pedestrian traffic that persistently uses streets for a variety of reasons, and for as many hours of the day as possible;

2. Short blocks to find different paths, allowing exploration en route to any given destination;

3. Mixture of building ages, so that differing rents can be charged, allowing for tenants from a broader economic spectrum;

4. Sufficient density of people, both residents and non-residents, using the streets for a multitude of reasons.

The first condition focuses on the ability for areas of cities to attract people operating on different schedules, so that each successive/overlapping wave of users can provide the services that residents and visitors inherently provide for vitality and security; specifically, these services include driving economic activity and delivering indirect neighborhood policing through their presence ("eyes on the street"). Users are drawn in by primary diversity (residences, businesses, certain retail clusters), which then stimulates further economic activity through secondary diversity (food service, retailers and other services) that serves the needs of those anchored by primary diversity. This condition naturally favors active transportation modes (walking and cycling).

The second condition for diversity stipulates that in order to ensure a constant flow of pedestrian traffic through an area, small blocks are required. The rationale behind this is that short blocks offer wider options of way-finding for users seeking to traverse a given area. This free flow of street users prevents stagnant zones that are unable to attract passive activity; in the absence of activity, Jacobs suggests economic decay can occur (due to lack of walk-in clientele), thus increasing the potential for crime and decreasing the sense of safety. Short blocks can directly encourage pedestrian activity and discourage car use (Lotfi and Koohsari 2011; Yin 2013; Ewing and Cervero, 2010).

The third condition for diversity suggests that a mixture of building ages offers the opportunity for an assortment of users to occupy them. New buildings and their 
Please Cite as: Mohareb, E., Derrible, S., and Peiravian, F. (2015). "Intersections of Jane Jacobs' Conditions for Diversity and Low-Carbon Urban Systems: A Look at Four Global Cities." J. Urban Plann. Dev. , 10.1061/(ASCE)UP.1943-5444.0000287 , 05015004.

associated higher rents typically house high-yield businesses. Jacobs suggests these types of businesses can be limited to chain restaurants/retailers, financial sector operations, and supermarkets. Niche enterprises that would provide novel services to emerging consumer groups require older buildings with lower rents. These buildings are the incubators necessary for small businesses and organizations to develop and thrive. While the implications for sustainability are indirect, this condition promotes heterogeneity (unlike residential sprawl, which favors homogeneity in the physical, economic, and demographic sense); this can further encourage active transportation.

Jacobs' final condition for diversity is one that she suggests is well established: the need for a sufficient concentration of people/businesses to provide the users of a mixture of primary and secondary diversity. It is necessary that density not be pursued for the sake of density alone, and that the other three conditions are considered in conjunction. Examples of urban developments that do not incorporate the other three conditions are single-use housing projects, which can have high density yet fail to produce the desired economic vibrancy because they are standardized monoculture (with respect to use, building age, and character). Jacobs sees the optimal residential density being somewhere between 100-200 units per net acre of residential land.

Increased density has two notable impacts on the sustainability of cities: lower transportation energy and lower energy requirements for lighting and space conditioning (i.e. reduced floor area per unit/capita). A further benefit around density promotion is the mitigation of the urban heat island; some studies have shown that low density urban form can lead to a greater heat island effect per housing unit due to a decrease in surface albedo from the conversion of forested areas to lawns (Ko, 2013). This can lead to a reduction in cooling energy demand per unit of housing, building urban resilience to extreme heat events.

The theories Jacobs put forward on the conditions that contribute to a vibrant urban center have been adopted in planning discourse internationally (Grant, 2002; Oktay, 2004; King, 2013). Jacobs herself recognized the contribution made by her theory on generating diversity, stating: "The necessity for these four conditions is the most important point this book has to make" (p.151). Naturally, most cities tend to possess neighborhoods that share some or all of these conditions. Figure 1 shows such neighborhoods for each of the four cities being assessed here (with a sample street view on the left-hand side and a map view on the right-hand-side). Nevertheless, not only are the data that illuminate whether or not Jacobs' conditions are observed in a city difficult to obtain (especially urban-scale data on the mixture of building ages), these conditions can be manifested in many different ways. For example, the urban form providing the population density in Figure 1b) from Chicago is different from that in Figure 1d) from Singapore. The analysis provided below attempts to substantiate a relationship between Jacobs' conditions and urban GHG mitigation through the exploration of four different case study cities. 
Please Cite as: Mohareb, E., Derrible, S., and Peiravian, F. (2015). "Intersections of Jane Jacobs' Conditions for Diversity and Low-Carbon Urban Systems: A Look at Four Global Cities." J. Urban Plann. Dev. , 10.1061/(ASCE)UP.1943-5444.0000287 , 05015004.

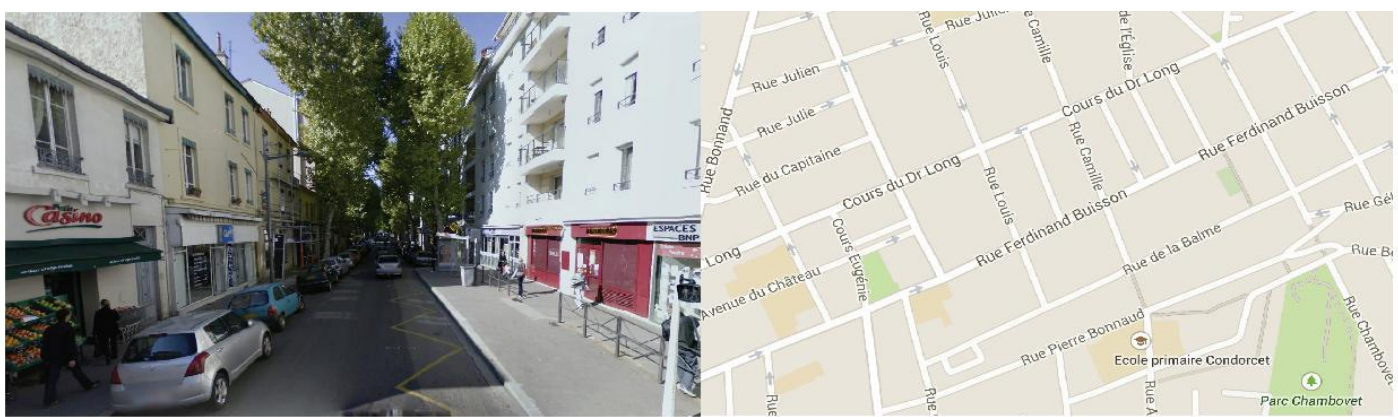

a) Lyon

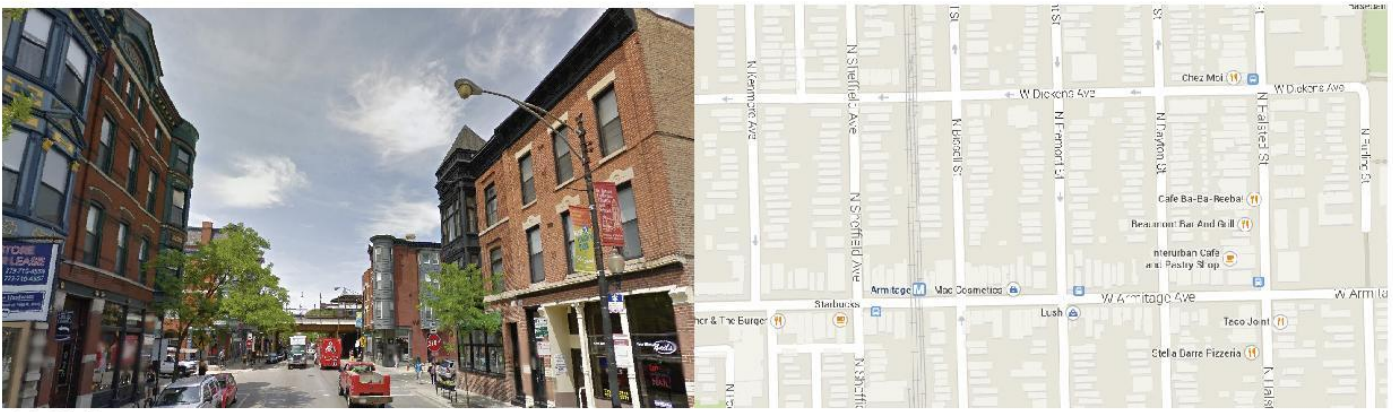

b) Chicago

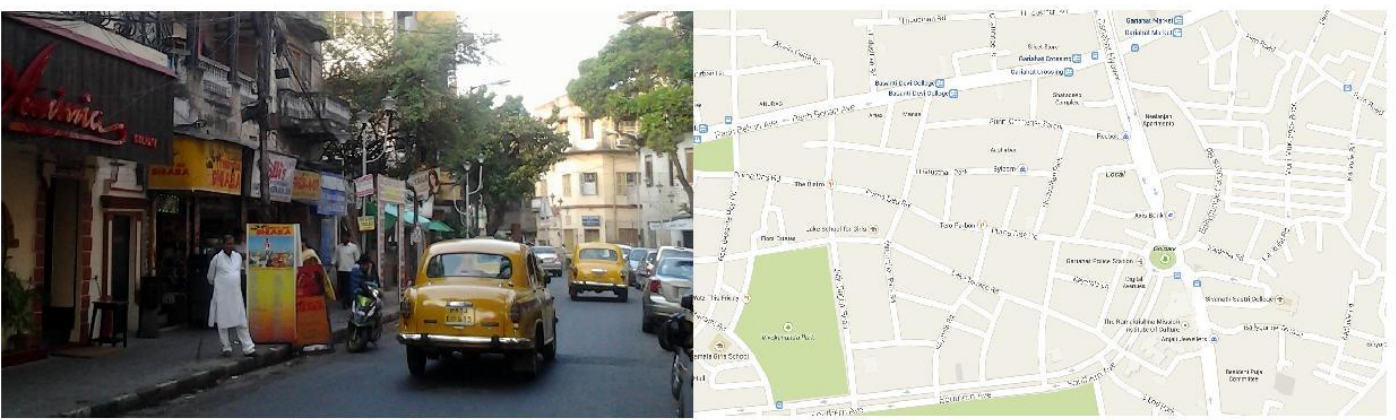

c) Kolkata
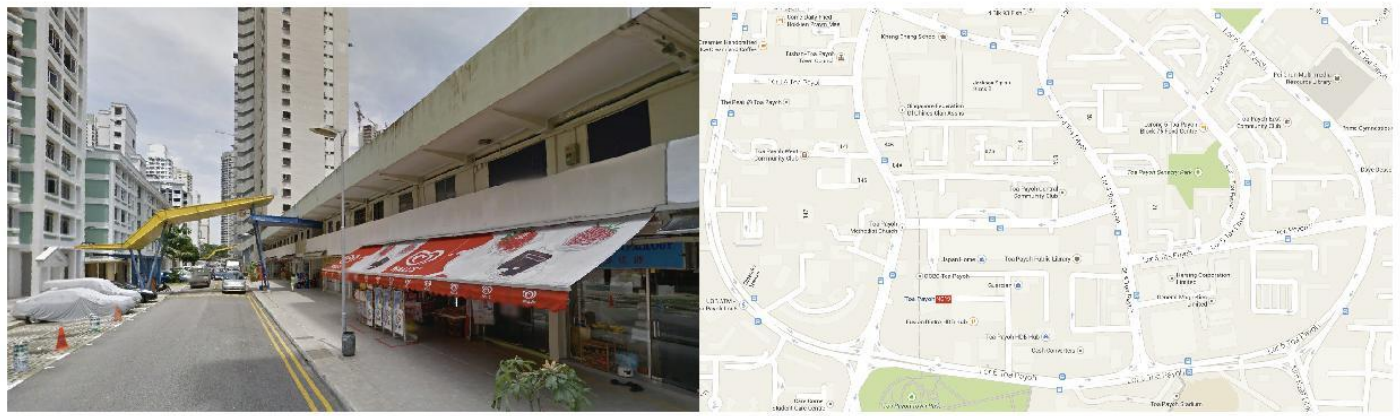

d) Singapore

Figure 1: Neighborhoods exhibiting some or all of Jacobs' conditions. Source for Lyon, Chicago and Singapore: Google Street View and Google Maps; Source for Kolkata: personal photo and Google Map. 
Please Cite as: Mohareb, E., Derrible, S., and Peiravian, F. (2015). "Intersections of Jane Jacobs' Conditions for Diversity and Low-Carbon Urban Systems: A Look at Four Global Cities." J. Urban Plann. Dev. , 10.1061/(ASCE)UP.1943-5444.0000287 , 05015004.

\section{The Four Cities}

The four cities studied in this article are: Lyon (France), Chicago (US), Kolkata (India), and Singapore (Singapore). In this section, we offer a historical account of each city to provide context for the GHG analysis and comparison to Jacobs' conditions in following sections. This is paramount since a city's development context is an important factor influencing its land-use. Therefore, while arguing for more compact land-use in Chicago, for instance, may be sensible and achievable, it is more challenging in the historically rich city of Lyon, with its UNESCO (United Nations Educational, Scientific, and Cultural Organization) recognized buildings. Similarly, arguing for a mixture of building ages in Singapore is not practical, considering most of the land was developed after it gained independence from Malaysia in the 1960s. Table 1 lists various characteristics from each city that has influenced their growth, urban form and infrastructure development, differing sufficiently to make their comparison with Jacobs' conditions unique. These factors provide each city with unique characteristics, which dictate the types of policies and infrastructure projects that can be carried out locally towards GHG mitigation. Table 2 offers detailed indicators about each city. These indicators pertain to all aspects of this work, including the three dimensions that are discussed below.

Table 1: Characteristics influencing urban form and development in the four cities studied

\begin{tabular}{lllll}
\hline \hline Characteristic & Lyon & Chicago & Kolkata & Singapore \\
\hline Year founded & 43 BCE & $1837 \mathrm{CE}$ & $1690 \mathrm{CE}$ & $1819 \mathrm{CE}$ \\
$\begin{array}{l}\text { Development } \\
\text { Status }\end{array}$ & Developed economy & Developed economy & Emerging economy & Developed economy \\
$\begin{array}{l}\text { Infrastructure } \\
\text { Status }\end{array}$ & $\begin{array}{l}\text { Historic \& modern } \\
\text { infrastructure }\end{array}$ & Modern infrastructure & Historic \& modern & Modern \\
Population & Stable population & Stable population & Growing population & Growing population \\
$\begin{array}{l}\text { Dynamics } \\
\text { Governance }\end{array}$ & Established & Established & Recently & infrastructure \\
Status & democracy & democracy & independent & Recently \\
\hline \hline
\end{tabular}


Please Cite as: Mohareb, E., Derrible, S., and Peiravian, F. (2015). "Intersections of Jane Jacobs' Conditions for Diversity and Low-Carbon Urban Systems: A Look at Four Global Cities." J. Urban Plann. Dev. , 10.1061/(ASCE)UP.1943-5444.0000287 , 05015004.

Table 2: Summary of metrics related to dimensions for comparing Jacobs' conditions for diversity and GHG emissions for Lyon, France

\begin{tabular}{|c|c|c|c|c|c|c|c|c|c|c|}
\hline City & $\begin{array}{l}\text { Population }^{1} \\
\text { (2008) }\end{array}$ & $\begin{array}{c}\text { Population } \\
\text { Density }^{1} \\
\left(\text { per } \mathbf{k m}^{2}\right)\end{array}$ & $\begin{array}{l}\text { Decades of } \\
\text { Peak } \\
\text { Population } \\
\text { Quartiles }^{2}\end{array}$ & $\begin{array}{c}\text { Mode Share } \\
\text { (2008) }\end{array}$ & $\begin{array}{c}\text { Average } \\
\text { Road } \\
\text { Density } \\
\left(\mathbf{k m} / \mathbf{k m}^{2}\right)^{4}\end{array}$ & HDD $^{5}$ & $\mathrm{CDD}^{6}$ & Climate $^{7}$ & $\begin{array}{c}\text { Hot } \\
\text { Months }^{8}\end{array}$ & $\begin{array}{c}\text { Annual } \\
\text { Wet } \\
\text { Days }^{9}\end{array}$ \\
\hline Lyon & $\begin{array}{c}1,269,257 \\
\text { (Lyon) } \\
1,516,061 \\
\text { (Grand } \\
\text { Lyon) }\end{array}$ & $\begin{array}{c}9,874 \\
\text { (Lyon) } \\
2,460 \\
\text { (Grand } \\
\text { Lyon) }\end{array}$ & $\begin{array}{c}1^{\text {st }}-\text { pre- }-1840 \\
2^{\text {nd }}-1890 \mathrm{~s} \\
3^{\text {rd }}-1960 \mathrm{~s} \\
4^{\text {th }}-2000 \mathrm{~s}\end{array}$ & $\begin{array}{c}\text { - Private: } 58 \% \\
\text { - Public: } 25 \% \\
\text { - Walking: } 10 \% \\
\text { - Two-wheels: } \\
4 \%\end{array}$ & 9.87 & 2473 & 454 & $\begin{array}{c}\text { Humid } \\
\text { Subtropical }\end{array}$ & 0 & 145 \\
\hline Chicago & $\begin{array}{c}2,695,598 \\
\text { (Chicago) } \\
5,194,675 \\
\text { (Cook } \\
\text { County) }\end{array}$ & $\begin{array}{c}7,360 \\
\text { (Chicago) } \\
3,414 \\
\text { (Cook } \\
\text { County) }\end{array}$ & $\begin{array}{l}1^{\text {st }}-1890 \mathrm{~s} \\
2^{\text {nd }}-1910 \mathrm{~s} \\
3^{\text {rd }}-1940 \mathrm{~s} \\
4^{\text {th }}-1970 \mathrm{~s}\end{array}$ & $\begin{array}{c}\text { - Private: } 73 \% \\
\text { - Public: } 10 \% \\
\text { - Walk: } 14 \% \\
\text { - Bike: } 1 \% \\
\text { - Other: } 2 \%\end{array}$ & 10.18 & 3353 & 654 & $\begin{array}{c}\text { Humid } \\
\text { Continental }\end{array}$ & 0 & 124 \\
\hline Kolkata & $4,496,694$ & 24,306 & $\begin{array}{c}1^{\text {st }}-1920 \mathrm{~s} \\
2^{\text {nd }}-1940 \mathrm{~s} \\
3^{\text {rd }}-1980 \mathrm{~s} \\
4^{\text {th }}-2000 \mathrm{~s} \\
\end{array}$ & $\begin{array}{c}\text { Public - } 82 \% \\
\text { Private - } 2 \% \\
\text { Walk - } 16 \%\end{array}$ & $8.22^{10}$ & 96 & 3244 & $\begin{array}{l}\text { Tropical } \\
\text { wet-and- } \\
\text { dry }\end{array}$ & 8 & 84 \\
\hline Singapore & $5,399,200$ & 7,428 & $\begin{array}{l}1^{\text {st }}-1960 \mathrm{~s} \\
2^{\text {nd }}-1980 \mathrm{~s} \\
3^{\text {rd }}-1990 \mathrm{~s} \\
4^{\text {th }}-2010 \mathrm{~s}\end{array}$ & $\begin{array}{c}\text { - Private: } 29 \% \\
\text { - Public: } 44 \% \\
\text { - Walk: } 22 \% \\
\text { - Bike: } 1 \% \\
\text { - Taxi: } 4 \%\end{array}$ & 6.75 & 0 & 3571 & $\begin{array}{l}\text { Tropical } \\
\text { wet-and- } \\
\text { dry }\end{array}$ & 8 & 84 \\
\hline
\end{tabular}

${ }^{1}$ Sources: Lyon \& Grand Lyon (UrbaLyon, 2011), Chicago \& Cook County (US Census, 2013), Singapore (SingStat, 2011), Kolkata (Census of India, 2011); ${ }^{2}$ These refer to the decades in which mark the division of the quartiles of the peak population ( $25 \%$ of peak, $50 \%$ of peak, etc.) observed in Figure 2; ${ }^{3}$ Sources: Grand Lyon - UrbaLyon (2011), Cook County - Journey to work only - CMAP (2010), Kolkata (WWF, 2010), Singapore (LTA, 2011); ${ }^{4}$ See Figure $3 ;{ }^{5} \mathrm{HDD}$ : Heating Degree Days; ${ }^{6} \mathrm{CDD}$ : Cooling Degree Days; Source: www.degreedays.net with an $18^{\circ} \mathrm{C}$ base temperature. ${ }^{7}$ Köppen Climate Classification; ${ }^{8}$ Months where the average daily maximum temperature exceeds $30^{\circ} \mathrm{C}$; Source: worldweather.wmo.int; ${ }^{9}>0.1 \mathrm{~mm}$ of rain, Source: www.bbc.co.uk/weather; ${ }^{10}$ Value calculated for $500 \mathrm{~km}^{2}$ area around the city center as shown in Figure 3 with incomplete data.

\section{Lyon}

Lyon is a historical city, developed in traditional European style. It is the capital of the Rhône-Alpes region and is the second biggest urban area in France after Paris, with a city of Lyon population of 0.5 million, a Grand Lyon population of 1.5 million, and a Lyon Urban Area population of nearly 2.2 million (compared with Paris' 10.3 million inhabitants (INSEE, 2015)). Lyon is a typical European city that existed through centuries of cultural and social evolution. Also akin to many European cities, the Central Business District (CBD) of Lyon, "Part-Dieu" (the second largest business district in France, which also houses a major shopping center), is not located in its historical center of the "Presqu'île". The historical center has turned into a major commercial area (shops and restaurants), institutional area (City Hall, museums), and residential area (with 5-8 story buildings). The original city of Lyon arguably possesses Jacobs' conditions, but the Grand Lyon demonstrates elements of modernist design, especially in the suburbs with its infamous banlieues (i.e. low-income neighborhoods with high crime rates). For a compelling historical account of Lyon, see Pelletier et al. (2007). 
Please Cite as: Mohareb, E., Derrible, S., and Peiravian, F. (2015). "Intersections of Jane Jacobs' Conditions for Diversity and Low-Carbon Urban Systems: A Look at Four Global Cities." J. Urban Plann. Dev. , 10.1061/(ASCE)UP.1943-5444.0000287 , 05015004.

Lyon's population since 1841 (as well as the Rhône Department, an administrative area larger than the Grand Lyon) is presented in the time series in Figure 2. The populations of Lyon and the Rhône Department have been relatively stable with steady increases since the 1840 s.

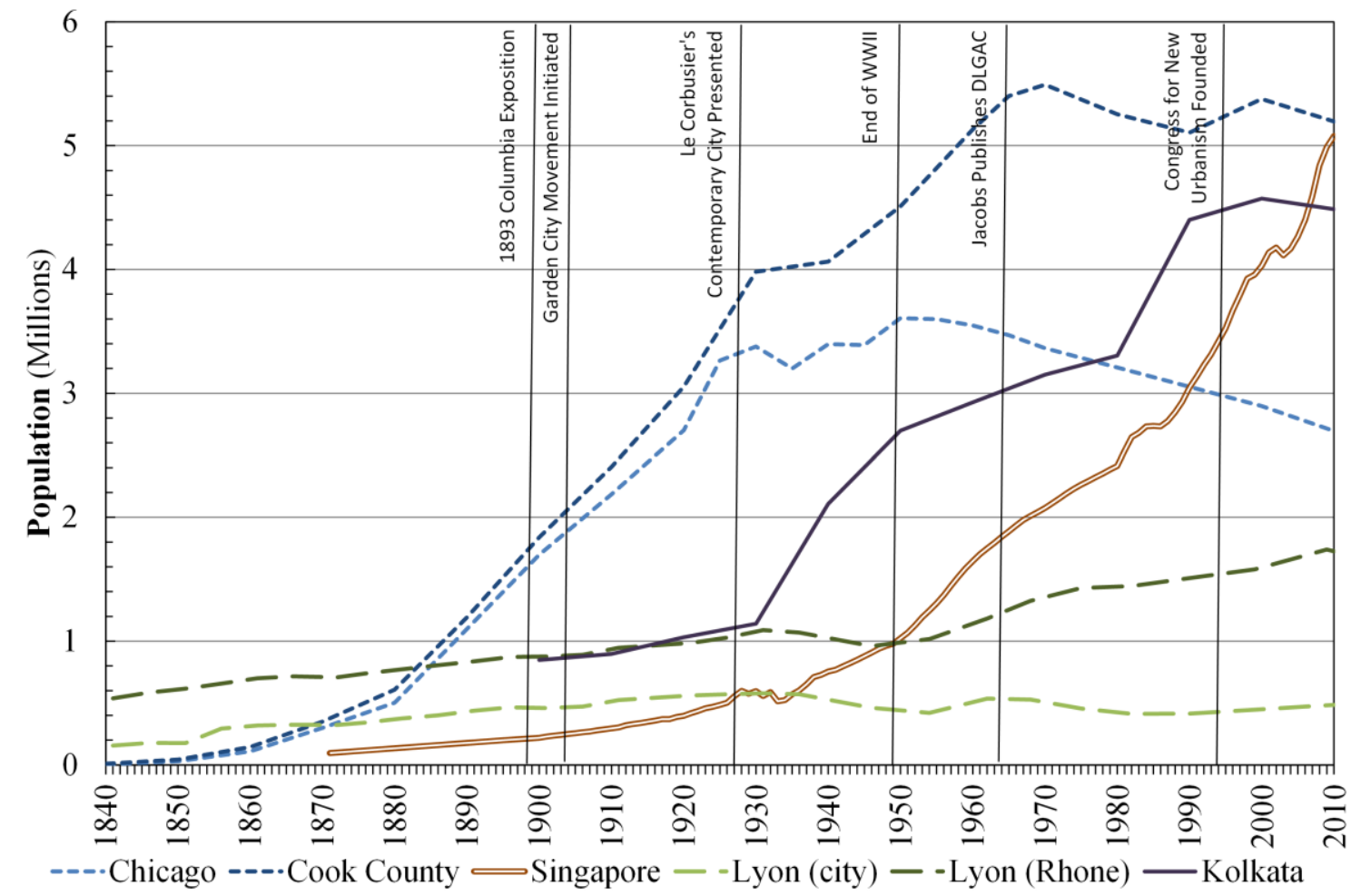

Figure 2: Evolution of population. Sources: Lyon \& Rhone (Annuaire-Mairie, 2013; INSEE, 2013), Chicago \& Cook County (US Census, 2013; IGPA, 1973), Singapore (Populstat, 2013; World Bank, 2013a), Kolkata (Cox, 2012).

The relatively stable population over the past century suggests that the city's approach to infrastructure development/use is in a maintenance/redevelopment phase. This is sometimes at the expense of historical neighborhoods with former Mayor Louis Pradel's major infrastructure undertakings in the 1960s and 1970s. Nonetheless, Lyon has retained much of its historic building stock, including the St-Jean neighborhood with its Roman and medieval heritage. Lyon's population reached $75 \%$ of its peak population in the 1920s, suggesting that much of its infrastructure was established prior to widespread personal mobility, limiting the potential for low-density housing. Additionally, this presents an opportunity for mixed-age buildings, though tracking redevelopment of buildings quantitatively is difficult. As well, this indicates that broader urban form was primarily decided in an era of reduced mobility, high density development (a preponderance of mid-rise buildings), and lower per-capita energy consumption (relative to the modern context). For the Grand Lyon region, automobiles are the primary mode of transportation by providing $58 \%$ of all trips, though this mode share decreases to $44 \%$ for the older, denser city of Lyon (UrbaLyon, 2011). 
Please Cite as: Mohareb, E., Derrible, S., and Peiravian, F. (2015). "Intersections of Jane Jacobs' Conditions for Diversity and Low-Carbon Urban Systems: A Look at Four Global Cities." J. Urban Plann. Dev. , 10.1061/(ASCE)UP.1943-5444.0000287 , 05015004.

Lyon's climate requires space heating and, to a lesser extent, space cooling. Most heating is provided through natural gas and heating oil, contributing to the community GHG total. There are few physical constraints on growth, with surrounding agricultural land allowing for the potential of urban expansion. Most of the growth, however, has historically followed the two rivers, the Rhône and the Saône, notably due to easy access to water transportation modes, thus providing an incentive for relatively dense land-use.

\section{Chicago}

Chicago is a contemporary American city, located within Cook County, Illinois. The CBD is second in the US for employment totals (New York City being the largest; Demographia, 2006). Chicago was home to the famous 1893's Columbian Exhibition, which provided inspiration to the monument-focused City Beautiful movement, through its primary planner Daniel Burnham (Jacobs 1961, p.24. The broader Cook County's population more or less stabilized in the 1970s, experiencing its most rapid population growth in the early-to-mid twentieth century; as a result, the urban form follows the modernist thinking popularized during this growth era. Chicago's CBD is predominantly occupied by commercial buildings, high-rise residential buildings and institutions. The City of Chicago reached its peak population in 1950 (3.6 million) and has gradually declined since (McClendon, 2013). Much of the growth over the past 50 years has occurred in the suburban areas surrounding Chicago, akin to most cities in North America, and symptomatic of the well-documented urban decline phenomenon (Glaeser and Kohlhase, 2003; Burchfield et al., 2006). Chicago is of particular interest for this study since it possesses both traditional-style planning (e.g., North of the Chicago River) that diligently follows Jacobs' conditions as well as massive suburban development and sprawl. A short, yet thorough, account of Chicago can be found in Mills (2001).

Chicago's population has stabilized in recent decades, suggesting that infrastructure projects are currently focused on redevelopment and maintenance. Cook County entered the 4th quartile of its peak population in the 1940s, allowing for age diversity in the building stock. An important point to note is that simultaneous growth and decline in population occurred in Cook County and Chicago, respectively, after World War II, suggesting a migration to the suburban areas of the population. Declines in the population in recent years (observed predominantly in the City of Chicago, but also in Cook County) also point to declining density. In Chicago, private automobiles are the dominant mode choice, providing for close to three-quarters of all trips (note that this value is lower relative to the entire Chicago region, where the car provides for $86 \%$ of the trips). Considering this, along with the post-war suburban migration, an energy and GHG intensive urban form (low-density, suburban living) has resulted in the region's transportation sector.

Chicago's eastern boundary is strictly maintained by Lake Michigan, though its expansion to the relatively flat agricultural land surrounding it has allowed a great deal of growth of single-family housing in its suburbs and cities within its commutershed (e.g. 
Please Cite as: Mohareb, E., Derrible, S., and Peiravian, F. (2015). "Intersections of Jane Jacobs' Conditions for Diversity and Low-Carbon Urban Systems: A Look at Four Global Cities." J. Urban Plann. Dev. , 10.1061/(ASCE)UP.1943-5444.0000287 , 05015004.

Naperville, Arlington Heights). Its climate is dominated by winters, which warrant significant space heating, driving GHG emissions from heating fuels, and can also influence transportation mode selection.

\section{Singapore}

Singapore has a compelling history, evolving from developing to developed country status in less than 50 years. Located in the Singapore Strait, it was a British colony for nearly 150 years before it first joined Malaysia in 1963, to then become independent in 1965. Its population increased nearly threefold from 1.9 million in 1965 to 5.2 million in 2011 as it can be seen from Figure 2. In the same time period, Singapore's GDP increased by a staggering factor of 246 and its GDP per capita increased by a factor of 90 in real terms (World Bank, 2013). To achieve such growth, Singapore has invested heavily in its infrastructure and in research and development. It effectively shifted its main economy of "low-end commerce" (EDB, 2015) to a diverse and developed economy where both the industrial and financial sectors thrive. The government also established a massive public housing scheme under the Housing Development Board, housing about $82 \%$ of the residential population and reaching $88 \%$ home ownership rates in 2010 (SingStat, 2011). Jacobs' concepts are ingrained in planning these housing projects, which also include "various commercial, recreational, and social facilities and amenities" (HDB, 2014). In fact, the Singapore planning authority, the Urban Redevelopment Authority (URA, 2015), established a distinct zoning code for "Commercial \& Residential" developments. These mixed-used zones can be found everywhere in the island (see Singapore Master Plan 2014 (URA 2014)). Today, Singapore is generally seen as a model for growth for many cities in developing countries. For a fascinating historical account, the reader is referred to Lee Kuan Yew's memoirs (Yew, 2000).

During its transition to developed-country status, Singapore has witnessed a substantial population increase, with an average and sustained per annum rate of $2 \%$ since 1960. However, Singapore is currently facing two major demographic challenges, an aging population coupled with a low fertility rate (1.2 compared to the replacement rate of 2.1), which will likely impact its future population growth (NTPD, 2013). The city's growth has occurred predominantly in the post-WWII era, a characteristic that in many countries would have meant low-density housing development; however, an exception is observed in Singapore thanks to government intervention. Much of Singapore's public and private housing is high-density, exhibited in multi-unit towers (Yuen, 2005). Given the lower floor space per unit and lower transportation energy demand observed, this type of development can facilitate lower GHG emissions as well as exhibit the density condition

Expectedly, public transportation is the main mode of travel in Singapore. Singapore is known for implementing strong road policies (such as its Electronic Road Pricing and comparatively high vehicle taxes; Debnath et al., 2011). While Schafer and Victor (2000) 
Please Cite as: Mohareb, E., Derrible, S., and Peiravian, F. (2015). "Intersections of Jane Jacobs' Conditions for Diversity and Low-Carbon Urban Systems: A Look at Four Global Cities." J. Urban Plann. Dev. , 10.1061/(ASCE)UP.1943-5444.0000287 , 05015004.

showed that economic development (i.e., GDP per capita) tends to be positively related to motorized kilometers traveled, this does not seem to apply to Singapore; it retains the highest GDP per capita of all four cities (see Table 4) while having lower levels of automobile use. The apparent success of Singapore's approach both resides in infrastructure investment (i.e., ample public transit options) and strong travel demand management policies (i.e., by making vehicle ownership prohibitively expensive).

Singapore's climate can be described as tropical (warm and humid), which has the potential to limit active transportation and, correspondingly, eyes on the street. However, the share of walking trips suggests this is not the case. Geographic constraints on its growth (being an island city-state) has necessitated a measured development of available land resources. In addition, given Singapore's limited energy resource wealth has shaped energy use planning (Chou, 1985).

\section{Kolkata}

Founded by the British in 1690, Kolkata has spent much of its history under colonial rule. The city served as the British administrative capital in India from 1773 until 1911 (when the capital was relocated to New Delhi), yet it remains an economic hub for the northeastern region of the country (Bhattacharya 2007; Bhatta, 2009). The city saw its most significant expansion during the $20^{\text {th }}$ century; Kolkata Municipal Corporation's (KMC) population growth increased steadily during the 1900's (from under a million to over 4.5 million by the turn of the century), with waves of new inhabitants made up of refugees and migrants from surrounding regions during the post-colonial period (Cox 2012; Banerjee and Das, 2006). An even greater share of regional population increase in the last half century has been concentrated in its suburban fringe (Bhattacharya, 2007; Cox, 2012). Urban form has followed the contemporary British model of the era, such as the inclusion of monumental buildings that were the foci in the European areas of the city. The early development of the city during the colonial era led to the formation of dense, multi-use areas (e.g. Gariahat, Park Street). An effort has been made to preserve this character, as has been observed in other colonial administrative capitals (such as Vientiane, Lao PDR; Long 2002). For a more detailed account of Kolkata's planning history, see Datta (2012).

Kolkata's population has significantly increased since 1930 (by a factor of nearly 4), as shown in Figure 2. While it seems to have stabilized in the 2000s, one should note that this data only shows population levels in the city of Kolkata (KMC), while its four neighboring regions have seen double digit growth since 1990 (Census of India, 2011). This spectacular demographic increase over the past century presents a challenge to planners, since it imposes stress on the urban economy, infrastructure, and energy demand. An indication of the difficulty the KMC has had in addressing the influx of inhabitants is the share of the population living in informal dwellings; in 2001, nearly a third of the population in the KMC lived in slums (Kundu, 2003). 
Please Cite as: Mohareb, E., Derrible, S., and Peiravian, F. (2015). "Intersections of Jane Jacobs' Conditions for Diversity and Low-Carbon Urban Systems: A Look at Four Global Cities." J. Urban Plann. Dev. , 10.1061/(ASCE)UP.1943-5444.0000287 , 05015004.

Public transportation dominates all other modes in Kolkata, likely due to economic constraints; regardless, congestion remains an issue due to limited road coverage (6\% total land area, relative to Chicago's 12\%) and high population density (Bardhan et al., 2011; Governance Knowledge Centre, 2008; Nowak \& Greenfield, 2012).

No major geographic constraints in the region immediately surrounding the KMC exist to present a barrier to its spatial expansion, though the economic and energy challenges that the city faces inhibit the low density development prevalent in jurisdictions that are well-serviced by passenger vehicles. The relatively warm climate limits the demand for heating fuels, though its high number of CDDs and increasing income provide conditions for rises in electricity demand for space cooling, in addition to other consumption-related electricity grid carbon emissions.

\section{Framework for Comparing Jacobs' Conditions and GHG Emissions}

To compare the four cities, we have selected three dimensions that are both pertinent to Jacobs' conditions for diversity as well as to low-carbon cities. These three dimensions are:

1. Population and Density

2. Infrastructure Development/Use

3. Climate and Landscape

Elements of both dimensions one and two are commonly used to consider matters around urban energy use and GHG emissions (Chavez and Ramaswami, 2013; Kennedy et al., 2009, Baur et al., 2014). Population dynamics and population density are related to Jacobs' density condition. A number of studies have attempted to demonstrate the importance of population density in reducing energy use and associated GHG emissions (Kennedy et al, 2009; Norman et al, 2006; Newman and Kenworthy, 1989)

The second dimension is assessed through an examination of infrastructure development, transportation mode share, and road density, exploring Jacobs' conditions on short blocks. Additionally, through an examination of population growth over time and density, inferences are made on the age of the building stock (this data is unavailable at the urban scale for the cities being studied). To do this, we quantify the stages when each quartile was reached relative to the city's peak population. The Infrastructure Development/Use dimension also illustrates the indirect relationships with the other two conditions in that these both have a need for pedestrian activity, which further drives eyes on the street.

Although atypical in urban planning comparisons, Climate and Landscape can have tremendous impacts on decisions related to GHG mitigation and the manifestation of Jacobs' conditions (the humid climate in Singapore may be a deterrent to walking, for instance). From the perspective of the conditions for diversity, the implications of climate on pedestrian traffic (street users) and their resultant "eyes on the street" can be 
Please Cite as: Mohareb, E., Derrible, S., and Peiravian, F. (2015). "Intersections of Jane Jacobs' Conditions for Diversity and Low-Carbon Urban Systems: A Look at Four Global Cities." J. Urban Plann. Dev. , 10.1061/(ASCE)UP.1943-5444.0000287 , 05015004.

substantial (Chen and Ng, 2012; Nankervis, 1999). For example, studies in temperate climates suggest trips by active modes of transportation are sensitive to cold and warm weather conditions (Miranda-Moreno and Lahti, 2013; Saneinejad et al., 2012; Bergström and Magnusson 2003). Additionally, urban form (and, consequently, GHGs in alignment with Jacobs' conditions) can be influenced by landscape, as physical constraints on development such as mountains or water bodies (such as is observed in Vancouver by Davis and Schaub (2005); see further discussion of Singapore and Chicago below).

Naturally, many more dimensions can be applied, including zoning, local policies, economic activity, amongst many others; however, these three were selected at present due to data availability and their applicability in aggregate form. A summary of the relevant factors within each criterion is provided in Table 3, along with relevant urban metrics for quantifying these. Associated conditions for diversity and drivers of GHG emissions are also presented.

Table 3: Summary of key data used in the three dimensions for assessing the relationship between Jacobs' conditions for diversity and GHG emissions

\begin{tabular}{|c|c|c|c|}
\hline Dimension & Related Metric & $\begin{array}{l}\text { Associated Conditions } \\
\text { for Diversity }\end{array}$ & $\begin{array}{l}\text { Associated Driver of } \\
\text { GHG Emissions }\end{array}$ \\
\hline $\begin{array}{l}\text { Population and } \\
\text { Density }\end{array}$ & 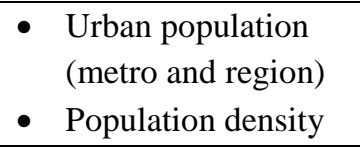 & - Density & $\begin{array}{ll}- & \text { Total energy demand } \\
\text { - } & \text { Building energy use } \\
& \text { (dwelling size) }\end{array}$ \\
\hline $\begin{array}{l}\text { Infrastructure } \\
\text { Development /Use }\end{array}$ & 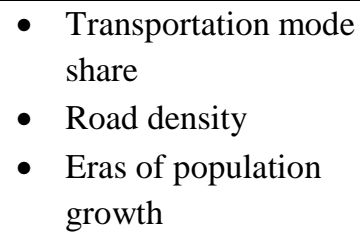 & $\begin{array}{ll}\text { - } & \text { Short blocks } \\
\text { - } & \text { Mixed building age } \\
\text { - } & \text { Density (indirect) } \\
\text { - } & \text { Multiple uses } \\
& \text { (indirect) }\end{array}$ & $\begin{array}{l}\text { - Transportation energy } \\
\text { demand } \\
\text { - Building energy use }\end{array}$ \\
\hline $\begin{array}{l}\text { Climate and } \\
\text { Landscape }\end{array}$ & $\begin{array}{l}\text { - Heating/cooling } \\
\text { degree days } \\
\text { - Hot months } \\
\text { - Annual wet days }\end{array}$ & $\begin{array}{ll}\text { - } & \text { Density (indirect) } \\
\text { - } & \text { Multiple uses } \\
& \text { (indirect) }\end{array}$ & $\begin{array}{l}\text { - } \begin{array}{l}\text { Building energy } \\
\text { demand }\end{array} \\
\text { - Transportation energy } \\
\text { demand (indirect) }\end{array}$ \\
\hline
\end{tabular}

Census data from national statistical organizations are the primary source used for data used in this framework. Where this information was unavailable (e.g. data on municipal level gross domestic product (GDP), mode share), grey literature sources were consulted (see Table 2). Weather data is obtained from reputable sources (degreedays.net, World Meteorological Organization, British Broadcasting Corporation) rather than national weather data, to ensure consistent methodologies were used across the four cases. For the road density, geographic information systems (GIS) data was downloaded from 
Please Cite as: Mohareb, E., Derrible, S., and Peiravian, F. (2015). "Intersections of Jane Jacobs' Conditions for Diversity and Low-Carbon Urban Systems: A Look at Four Global Cities." J. Urban Plann. Dev. , 10.1061/(ASCE)UP.1943-5444.0000287 , 05015004.

the open access openstreetmap.org platform in shapefile format. The analysis was performed using ESRI's ArcGIS.

\section{Assessment of Jacobs' Criteria within Four Cities}

The following is an analysis of the performance of the four case study cities as they relate to the dimensions for assessing a city's adherence to Jacobs' conditions for diversity (provided above). This is predominantly done with the data collected in Table 2, whose relevance to Jacobs' conditions is described in Table 3.

\section{Population and Density}

Population and population density values for all four cities and their regions are listed in Table 2. In terms of population, Chicago, Kolkata and Singapore are larger cities, each with about 5 million inhabitants, while Lyon is relatively small with around 1.5 million in habitants. Naturally, population levels also vary depending on the regional extent that is being considered; for instance, the Chicago Metropolitan Statistical Area is reported to have 9.5 million inhabitants in 2013 (US Census, 2013) while the City of Chicago and Cook County were roughly one fourth and one half of this figure respectively in 2008 at 2.7 million and 5.2 million, respectively (see Table 2). Perhaps more importantly, historical population growth needs to be considered, displayed in Figure 2; as cities grow, their infrastructure stocks develop in tandem (or at least attempt to), influenced by changing planning and development trends (i.e., urban densities of the era, buildings constructed according to regulations of the day).

In Figure 2, major urban planning milestones are indicated to give some insight of the urban design trends of the era. Moreover, one can also get an impression of the population quartiles discussed in the previous section, which have a direct connection with land-use, as well as access to energy and transportation, and suggest the scale of infrastructure-of-the-day solutions that would have been applied. For example, we can infer that, during the divergence of population growth/decline between Cook County/Chicago from the 1930's onwards, auto-centric infrastructure dominated development.

Examining population densities Kolkata leads, followed by Singapore, Lyon, and Chicago. The case of Singapore is somewhat unique since, as an island city-state, its growth is constrained and its population is mostly concentrated in high-rises (Yuen, 2005). In contrast, Chicago is the least-dense city studied, although its density is higher than most US cities (US Census, 2013).

GHG emission data and a comparison of population density ranking (along with metrics from the other dimensions) are provided in Tables 4 and 5 respectively. The impact of population density on key metrics of sustainability (energy use, greenhouse gas 
Please Cite as: Mohareb, E., Derrible, S., and Peiravian, F. (2015). "Intersections of Jane Jacobs' Conditions for Diversity and Low-Carbon Urban Systems: A Look at Four Global Cities." J. Urban Plann. Dev. , 10.1061/(ASCE)UP.1943-5444.0000287 , 05015004.

emissions) is well known (Newman and Kenworthy, 1989; Norman et al., 2006; Codoban and Kennedy, 2008) and relates to Jacobs' conditions.

Although looking at densities of specific neighborhoods is more relevant to test the presence of Jacobs' conditions, citywide values provide some insights about the overall state of a city. It can be observed from Table 4 that density aligns with GHG emissions as well as transit/active mode shares.

Table 4: Comparison of rankings for per capita GHG emissions and indicators of Jacobs' conditions

\begin{tabular}{|c|c|c|c|c|c|c|}
\hline City & $\begin{array}{c}\text { Per } \\
\text { Capita } \\
\text { GHGs }^{1}\end{array}$ & $\begin{array}{l}\text { GHGs } \\
\text { from } \\
\text { Buildings }\end{array}$ & $\begin{array}{l}\text { GHGs } \\
\text { from } \\
\text { Transport }\end{array}$ & $\begin{array}{l}\text { Transit / } \\
\text { Active Mode } \\
\text { Share }\end{array}$ & $\begin{array}{l}\text { Population } \\
\text { Density }\end{array}$ & $\begin{array}{l}\text { Road } \\
\text { Density }\end{array}$ \\
\hline Grand Lyon & 2 & 2 & 3 & 3 & 3 & 2 \\
\hline Chicago & 4 & 4 & 4 & 4 & 4 & 1 \\
\hline Kolkata & 1 & 1 & 1 & 1 & 1 & 3 \\
\hline Singapore & 3 & 3 & 2 & 2 & 2 & 4 \\
\hline
\end{tabular}

${ }^{1}$ Oldest ranked first.

Similar to the historical perspective section, current density values can help determine what types of policies or infrastructure projects can be more effective. Arguing for higher densities in Kolkata may not be as relevant as in the suburban areas of Lyon and Chicago. However, as discussed in the introduction, development density in the spirit of what Jacobs suggests (e.g., those promoted by transit-oriented design or LEED-ND) can translate into improved GHG emissions performance in cities.

\section{Infrastructure Development/Use}

Transportation typically accounts for about one third of urban GHG emissions in developed cities and is also directly linked with the conditions for mixed uses, short blocks, and sufficient population density; these conditions tend to favor active and public transportation. Focusing more closely on transportation infrastructure, we calculated road densities for the four cities from openstreetmap data. Figure 3 shows road density for the four cities, where each square represents $1 \mathrm{~km}^{2}$. The black circles around the four cities represent exactly $500 \mathrm{~km}^{2}$, there were added to facilitate visualizing the relative extent of each city. The grid shades are associated with street density, in $\mathrm{km}$ of road per $\mathrm{km}^{2}$, with the intent to represent Jacobs' condition of short blocks; the darker the color, the greater the concentration of streets and, presumably, the shorter the blocks within this grid square. 
Please Cite as: Mohareb, E., Derrible, S., and Peiravian, F. (2015). "Intersections of Jane Jacobs' Conditions for Diversity and Low-Carbon Urban Systems: A Look at Four Global Cities." J. Urban Plann. Dev. , 10.1061/(ASCE)UP.1943-5444.0000287 , 05015004.

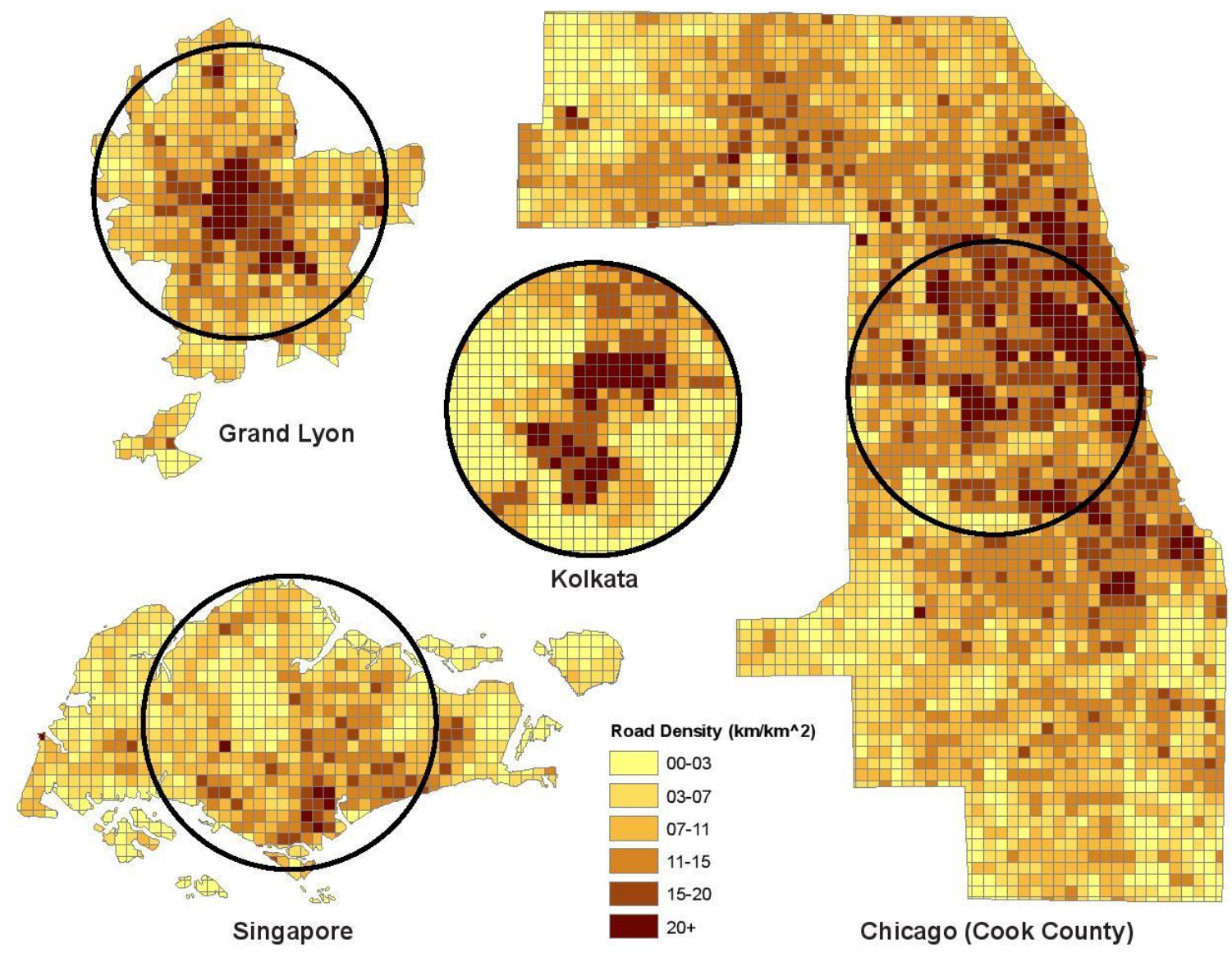

Figure 3: Map of road density. Source: OpenStreetMap Note: Data for Kolkata is incomplete; as a result, only the $500 \mathrm{~km} 2$ area centered on the downtown is shown.

One of the first observations we can make relates to the sheer size of the territories. Cook County, which represents about $15 \%$ of the complete Chicago Metropolitan Area, dwarves the three other cities. The Grand Lyon and Singapore share a relatively similar size, while the Kolkata Metropolitan Area (not completely shown) is about three times larger than the Grand Lyon.

Average road densities for the four cities were also calculated and they are shown in Table 2. With the exception of Kolkata for which accurate map data is not available, the GHGs from transport align with road densities, when ranking road densities lowest to highest and GHGs lowest to highest (see Table 4; note that, in the table, road density is ranked highest to lowest, in keeping with the Jacobs condition for short blocks). This agrees with the fact that road density may be either a driver and/or an outcome of transportation energy demand (Barr 2000; Cervero 2003; Noland 2001; Su 2010). The city of Chicago, located in Cook County, has the highest road density $\left(10.18 \mathrm{~km} / \mathrm{km}^{2}\right)$. Although some areas in the figure are artificially inflated by the presence of urban expressways, the grid system tends to favor high road densities. Advocating for smaller blocks by buildings more roads may actually promote more passenger vehicle trips (Barr 2000; Cervero 2003; Noland 2001; Su 2010). Once again, however, the sheer size of the 
Please Cite as: Mohareb, E., Derrible, S., and Peiravian, F. (2015). "Intersections of Jane Jacobs' Conditions for Diversity and Low-Carbon Urban Systems: A Look at Four Global Cities." J. Urban Plann. Dev. , 10.1061/(ASCE)UP.1943-5444.0000287 , 05015004.

Chicago region is a major deterrent to transit use. This is specifically relevant when many residents from the suburban areas that have low road densities travel to the CBD.

The next highest road densities are in Grand Lyon, Kolkata and Singapore, respectively. The differences between Singapore $\left(6.75 \mathrm{~km} / \mathrm{km}^{2}\right)$ and the Grand Lyon $\left(9.87 \mathrm{~km} / \mathrm{km}^{2}\right)$ are fairly substantial and may be instructive. Lyon shows much higher road densities in its central grid cells, which favor walk-trips and offer easier access to transit stops, owing to its long history (i.e. establishing its infrastructure without the broader commuter catchments enabled by motorized transportation). Singapore, on the other hand, has developed more recently, and has a relatively low road density throughout its entire area. Additionally, Singapore has a much lower vehicle ownership rate per capita than other countries of its income level (see Figure 4), thanks to policies in place to limit growth in this mode share (Olszewski 2007; Santos et al. 2010). Given this controlled low vehicle ownership rate (151 per 1000 people; relative to France's 582 per 1000 people), a high road density is simply not needed (neither are other passenger vehicle-related infrastructure). As well, Singapore has housing complexes that also integrate commercial space (see "The Four Cities" section above). Per Jacobs' first condition, this mixture of uses promotes walking trips that are therefore short and not necessarily on paved roads that would be shown on the online road density Figure.

Due to the lack of data for Kolkata, limited observations can be made from the map. Moreover, the value of $8.22 \mathrm{~km} / \mathrm{km}^{2}$ shown in Table 2 is misleading due to incomplete road and administrative data in the GIS files available. This value may be overestimating the actual road density since the full KMC is not included. As importantly, we have found through personal experience that paths intended for non-vehicle traffic tend not to be captured through OpenStreetMap, such as alleyways and other pedestrian paths, although they have an important function.

While Jacobs emphasizes the many benefits of short blocks and walkable cities in general, these can also provide upward pressure on emissions from transportation in two ways. Short blocks could lead to greater number of intersections, leading to an increased idling relative to longer blocks with fewer intersections. An example of the implications of idling on GHG emissions has been presented for New Delhi, India; $9 \%$ of total transportation emissions in the city were attributed to vehicles idling at intersections (Bhandari et al. 2013). At the same time, many studies have found that increases in roadway capacity leads to greater absolute transportation demand (Barr 2000; Cervero 2003; Noland 2001; Su 2010), though greater roadway density is also often associated with higher population density (as well as greater access to mixed uses) which provides lower VKT per capita (Cervero and Murakami 2010). The offsetting of transportation energy demand through an increase in pedestrian trips encouraged by road density may compensate for increases in GHG emissions, though this warrants further investigation. As well, pathway density should be emphasized over road density, with improved connectivity for active modes of transportation (cycle paths, pedestrian alleys, etc.) taking priority over the motor vehicle network. 
Please Cite as: Mohareb, E., Derrible, S., and Peiravian, F. (2015). "Intersections of Jane Jacobs' Conditions for Diversity and Low-Carbon Urban Systems: A Look at Four Global Cities." J. Urban Plann. Dev. , 10.1061/(ASCE)UP.1943-5444.0000287 , 05015004.

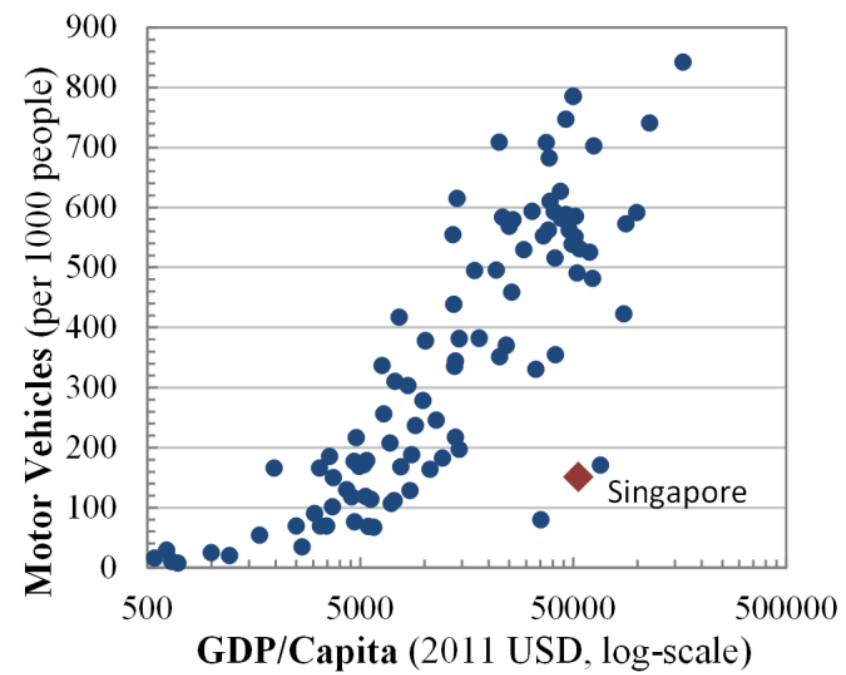

Figure 4: Motor Vehicle per 1000 People vs GDP per Capita, 2011 (Source: World Bank, 2015a; 2015b)

\section{Climate and Landscape}

Although climate may not be explicitly related to Jacobs' conditions, it can have a significant impact on diversity, urban form, and planning choices. Climate greatly influences energy needs of cities and their residents, which was briefly discussed in the context of the four cities in the previous section. This is particularly true in extremeweather climates, where temperature or precipitation events may reduce pedestrian trips; cities with mild climates may observe a greater increase in the pedestrian mode share from improved sidewalk infrastructure than those with more severe climates. Examination of the number of "wet days" (where precipitation exceeds $0.1 \mathrm{~mm}$ ) and monthly average temperatures can provide insight on extreme events within our profiled cities (Tables 2).

From a GHG perspective, climate and energy use are intrinsically related, with energy required for space conditioning of buildings. Typically, the number of heating degree days (HDD) and cooling degree days (CDD) are used to assess the importance of climate on energy for space conditioning (see Table 2). Moreover, past studies have highlighted the importance of climate on energy consumption and associated GHG emissions (Kennedy et al., 2009). Energy demand related to space conditioning requires attention, especially in cities with higher annual HDDs due to the comparatively higher energy intensity per unit of area for providing space heating versus cooling (Sivak, 2013). Studies have also suggested that cities with higher numbers of HDDs (such as Lyon and Chicago) can experience switches in mode from active to public or private transportation during the winter months, thus reducing "eyes on the street" and total available users (Miranda-Moreno and Lahti, 2013; Saneinejad et al., 2012; Bergström and Magnusson 2003). The same may occur in summer months in cities with high CDDs, as it is the case in Singapore and Kolkata, but walking and cycling can be encouraged through measures 
Please Cite as: Mohareb, E., Derrible, S., and Peiravian, F. (2015). "Intersections of Jane Jacobs' Conditions for Diversity and Low-Carbon Urban Systems: A Look at Four Global Cities." J. Urban Plann. Dev. , 10.1061/(ASCE)UP.1943-5444.0000287 , 05015004.

such as incorporation of street trees, covered/conditioned walkways, etc. (Foltete and Piombini, 2007; Johansson and Emmanuel, 2006).

Arguably, with a humid subtropical climate, no hot months and relatively few wet days, Lyon offers the best conditions for walking and cycling; coupled with its high density and short blocks, Jacobs' conditions and lower transportation energy demand are further encouraged. Chicago tends to experience extreme conditions in winter and summer, making the space-conditioned automobile a haven for its residents; this can further increase transportation GHG emissions. As mentioned, Singapore has provided some of Jacobs' conditions while accounting for its hot climate (i.e. by integrating commercial activity in public housing), serving as an example to Kolkata and other tropical cities in developing nations.

The density condition imposes a challenge in warmer regions; a number of anthropogenic sources of heat (buildings providing thermal mass, air conditioners expelling heat from building interiors, etc.) can increase the level of discomfort and cause an absolute increase in space cooling demand (Quah and Roth 2012). However, as stated earlier, Ko (2013) suggests that more dense urban settings result in lower cooling energy demand per household unit.

\section{Low-Carbon Systems and Jacobs' Conditions for Diversity}

Considering this work attempts to understand the intersections between Jacobs' principles and low-carbon cities, this section focuses on urban GHG drivers that are within the control of decision-makers that influence the urban realm. Areas that need improvement must be examined within a local context, instead of implementing one overarching planning strategy to all cities/neighborhoods. This section summarizes the relationship between Jacobs' conditions and their GHG implications relative to the three dimensions.

Accounting for the local context is important because the relationship between Jacobs' conditions and urban sustainability is non-linear; the application of one single condition can have multiple environmental benefits/detriments. To give a classic example, increasing population density will not only discourage driving and potentially reduce energy use per unit floor area (used for space conditioning), it can also increase accessibility of retail accessibility (Cervero and Murakami 2010). Additionally, an increase in energy demand to other goods and services (i.e., rebound effect) can occur due to reduced expenditures on transportation (Wiedenhofer et al. 2013). Identifying where cities can achieve the greatest net-benefit from these non-linear relationships may be key to achieving more sustainable outcomes.

We have argued that the presence of Jane Jacobs' conditions should be reflected in lower urban energy use and GHG emissions. Table 4 shows total and per capita emissions for the four cities, as well as a breakdown of emissions by sector. To demonstrate the perceived relationship between Jacobs' conditions and GHGs, rankings 
Please Cite as: Mohareb, E., Derrible, S., and Peiravian, F. (2015). "Intersections of Jane Jacobs' Conditions for Diversity and Low-Carbon Urban Systems: A Look at Four Global Cities." J. Urban Plann. Dev. , 10.1061/(ASCE)UP.1943-5444.0000287 , 05015004.

of the case study cities' performance in per capita emissions and metrics described above (see Table 3) are presented in Table 4. As will be discussed below, this seems to coincide with the central hypothesis that Jacobs' conditions correspond with low-carbon urban systems.

Table 5: Greenhouse gas (GHG) emissions and economic data for the four studied cities

\begin{tabular}{|c|c|c|c|c|}
\hline Metric & Grand Lyon ${ }^{1}$ & Chicago (city) ${ }^{2}$ & Kolkata $^{3}$ & Singapore $^{4}$ \\
\hline $\begin{array}{l}\text { Total }\left(\mathrm{Mt} \mathrm{CO}_{2} \mathrm{e}\right) \\
\text { (Inventory Year) }\end{array}$ & $7.6(2006)$ & $33.29(2010)$ & $9.33(2007-08)$ & $37.76(2000)$ \\
\hline $\begin{array}{l}\text { Per capita } \\
\left(\mathrm{t} \mathrm{CO}_{2} \mathrm{e}\right)\end{array}$ & 6.06 & 12.35 & 1.83 & 7.57 \\
\hline $\begin{array}{l}\text { Transport per capita } \\
\left(\mathrm{t} \mathrm{CO}_{2} \mathrm{e}\right)\end{array}$ & 1.76 & 3.83 & 0.33 & 1.16 \\
\hline $\begin{array}{l}\text { Buildings per capita } \\
\left(\mathrm{t} \mathrm{CO}_{2} \mathrm{e}\right)\end{array}$ & 1.03 & 3.62 & 0.35 & 1.13 \\
\hline \multirow[t]{5}{*}{ By sector } & $\begin{array}{l}40.9 \% \text { Industry + } \\
\text { Energy }\end{array}$ & $\begin{array}{l}39.8 \% \text { Electricity Use } \\
31 \% \text { Transport }\end{array}$ & $\begin{array}{l}54 \% \text { Industrial } \\
19 \%\end{array}$ & $\begin{array}{l}55.3 \% \text { Electricity } \\
\text { Generation }\end{array}$ \\
\hline & $29.1 \%$ Transport & $24 \%$ Natural Gas & Residential & $27.7 \%$ Industries \\
\hline & 17\% Residential & $1.6 \%$ Water (all) & $18 \%$ Transport & $15.3 \%$ Transport \\
\hline & $\begin{array}{l}\text { 12.7\% Commercial } \\
+ \text { Institutional }\end{array}$ & 2.7\% Solid Waste & 9\% Commercial & \\
\hline & $0.4 \%$ Agriculture & $0.4 \%$ Agriculture & & $\begin{array}{l}0.8 \% \\
\text { Commercial }\end{array}$ \\
\hline $\begin{array}{l}\text { GDP/Cap } \\
(\text { USD, 2012) }\end{array}$ & 41,038 & 54,953 & 3,127 & 62,523 \\
\hline $\begin{array}{l}\text { GDP/Cap Growth } \\
\text { (USD, 1993-2007) }^{5}\end{array}$ & $+1.9 \%$ & $+2.0 \%$ & $+5.0 \%$ & $+3.8 \%$ \\
\hline $\begin{array}{l}\text { GHG/GDP } \\
\left(\mathrm{kg}^{6} / \$ 2012\right)\end{array}$ & 0.15 & 0.22 & 0.59 & 0.12 \\
\hline \multicolumn{5}{|c|}{ 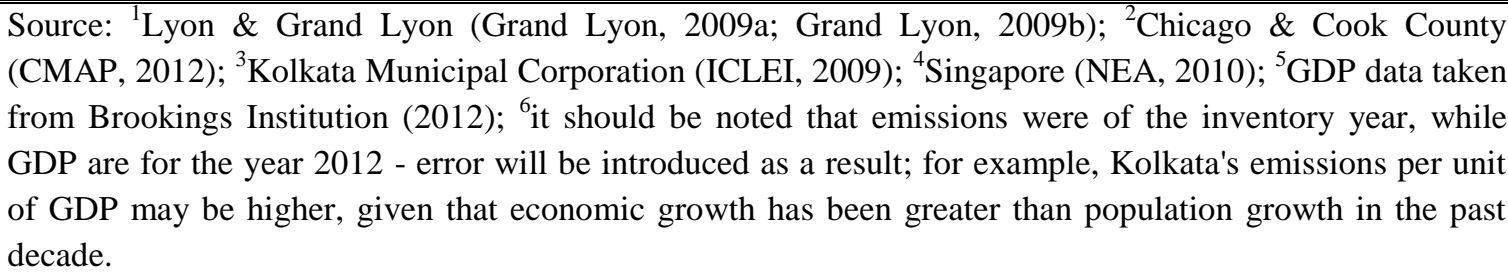 } \\
\hline
\end{tabular}

A first look at per capita emissions tells us unsurprisingly that Kolkatans are the lowest emitters, while Chicagoans are the highest emitters. Here again, the context of each city must be taken into account. For example, the Lyonnais benefit from a much cleaner electrical grid than the others, which helps maintain lower per capita emissions intensity in spite of it providing $28 \%$ of their energy usage. In 2009, grid emissions factors were estimated to be $30 \mathrm{kgCO}_{2} / \mathrm{MWh}$ compared to 559, 717, and 1000 $\mathrm{kgCO}_{2} / \mathrm{MWh}$ for Chicago, Singapore, and Kolkata, respectively (CARMA, 2015). As a 
Please Cite as: Mohareb, E., Derrible, S., and Peiravian, F. (2015). "Intersections of Jane Jacobs' Conditions for Diversity and Low-Carbon Urban Systems: A Look at Four Global Cities." J. Urban Plann. Dev. , 10.1061/(ASCE)UP.1943-5444.0000287 , 05015004.

city-state, per capita values for Singaporeans may be skewed since they include all national industries, unlike other urban inventories where regional specialization (as well as NIMBYism) may exclude important carbon-intensive sectors from inventories. Contrarily, Singapore may actually exclude certain carbon-intensive sectors due to its chosen economic specialization and geographic constraints.

Examining residential data GHG data, Chicago stands out with emissions that are more than three times Singapore (the next highest) even though the latter has newer buildings. Chicagoans are penalized in this comparison by their cold climate since they require more natural gas to heat their homes, representing $24 \%$ of the total emissions. It is possible that the availability of older buildings in accordance with Jacobs' may result in higher GHG emissions, as older buildings tend to be more energy intensive (for illustrations, see "Residential Sector" Table 9, OEE, 2012; and graph 5g, Department of Energy and Climate Change, 2013). These results suggest that the preservation of old buildings does not necessarily predestine a city to high building sector emissions. Other factors such as economic activity, climate, quality of the building stock, and carbon intensity of energy sources are likely more important. Additionally, in a social welfare state where governments are able to subsidize costs for occupants of newer buildings so as to encourage both varied population and businesses, new buildings may not pose the same diversity-deadening effect that Jacobs' observed. Further, from a policy perspective, ordinances that require reporting of energy performance of commercial/residential buildings can provide incentive for landlords of older buildings to maintain higher energy performance that would otherwise occur.

Focusing on transportation emissions (as these have the potential to be most directly influenced by Jacobs' conditions), the historic energy scarcity or passenger vehicle ownership may also influence the GHG emissions currently reflected by these municipalities. For example, given that the era in which much of the development in Kolkata and Lyon occurred, where there was limited passenger vehicles ownership during periods of population growth. Kolkata's rate of vehicle ownership in 2009 was roughly one-fifth of the Illinois average in 2010 (Bureau of Applied Economics \& Statistics, 2012; US Department of Transportation, 2011). Given that Kolkata's vehicle ownership recently reached this relatively low level, the city has mostly developed during an ear where most citizens could only travel by public or active modes of transportation, with urban form matching this constraint.

While the transport emissions can be compared more objectively, they simply tend to follow the transit mode share figures from Table 2, which we feel reflect the adherence to Jacobs' conditions. Transport emissions may also be telling of the urban form since longer trips are needed to reach a destination, thus arguably reflecting density and morphology (Bechle et al., 2011). Consequently, with $3.83 \mathrm{tCO}_{2} \mathrm{e}$ per capita and the relatively high automobile mode share, we can infer that Chicago has not adopted Jacobs' conditions to the same extent that Singapore, Kolkata, and Lyon have; however, it must be reiterated that these values may reflect the non-linear relationship mentioned above. 
Please Cite as: Mohareb, E., Derrible, S., and Peiravian, F. (2015). "Intersections of Jane Jacobs' Conditions for Diversity and Low-Carbon Urban Systems: A Look at Four Global Cities." J. Urban Plann. Dev. , 10.1061/(ASCE)UP.1943-5444.0000287 , 05015004.

The influence of economic factors in GHG emissions must not be neglected, given the correlation between income and emissions observed elsewhere (Kennedy et al, 2009; Ramaswami and Chavez 2013). As shown in Table 4, Kolkata's emissions per unit of GDP are less impressive than is suggested by the per capita figure, likely due to the prevalence of high-carbon fuels (e.g., coal) in the city's energy supply. Assuming that an environmental Kuznet's curve will apply for GHG emissions in the Indian case (see Lapinskiené, Tvaronavičiené, \& Vaitkus, 2014), a decoupling of economic growth and carbon emissions is likely occur at some point, though the timing of this is uncertain. As a result, increases in GHG emissions per capita can be expected to climb in Kolkata.

One point worth noting from Table 4 is that Kolkata consistently ranks well both in the metrics representing Jacobs' conditions and GHG emissions (on a per capita basis). While much of this can be attributed to low levels of income, policies that preserve these both Jacobs' conditions and low emissions during the expected era of economic growth will be important. Pricing roads (as Singapore did), preserving old buildings (along with the density they provide, as was done in Chicago and Lyon), and maintaining multiple uses of buildings (which all three have achieved) will be vital to this long-term effort.

It is worth highlighting that in the IPCC Fifth Assessment Report, Seto et al. (2014) present four metrics of urban form that influence GHG emissions. These metrics align well with Jacobs' conditions: density (condition for concentration of users), land-use mix (condition for attracting different users), connectivity (condition for short blocks), and accessibility (a combination of the three stated here). This provides additional support for the argument that Jacobs' conditions are an important consideration when planning the low-carbon city.

\section{Conclusion}

The main goal of this paper was to investigate the intersection of Jane Jacobs' conditions and low-carbon urban systems by studying four very different global cities. First, we listed Jacobs' conditions for diversity, discussing how they relate to the overarching goal of reducing lower energy use and GHG emissions. Second, we provided a brief historical overview of four case study cities and discussed the influence of their development on drivers of GHG emissions. The cities were then analyzed using three dimensions: Population and Density, Infrastructure Development/Use, and Climate and Landscape, to explore how Jacobs' conditions have manifested themselves and how this has affected their GHG emissions. Ultimately, the contribution of this work is the exploration of how Jacobs' conditions are exhibited in the four case study cities and the examination of how they influence GHG emissions in each case. We suggest that all four conditions for diversity can have a positive influence on GHG mitigation and that cities that display macro-scale characteristics indicative of the presence of Jacobs' conditions benefit from lower carbon emissions. 
Please Cite as: Mohareb, E., Derrible, S., and Peiravian, F. (2015). "Intersections of Jane Jacobs' Conditions for Diversity and Low-Carbon Urban Systems: A Look at Four Global Cities." J. Urban Plann. Dev. , 10.1061/(ASCE)UP.1943-5444.0000287 , 05015004.

Urban design professionals can take this conclusion from a general perspective, bearing in mind that Jacobs' conditions are manifested in many different ways in the case study cities. This is particularly relevant when considering historical, and climatic and landscape factors; for example, as an older, expansive city with a dense, low-rise core and relatively mild climate, Lyon exhibits Jacobs' conditions in a different way from Singapore, which is tropical, physically constrained, and has seen more recent infrastructural growth and contains many high rise buildings. In fact, the four cities selected in this study differ in many respects (eras of development, economic conditions, policy approaches, physical landscapes, etc.). Strategies to make them low-carbon must therefore be adapted to their individual contexts.

The four cities have different population densities, owing to the varying contexts of their growth. As well, they diverge in their road density, climate and reliance on passenger vehicles. We point to the relationship between carbon emissions and the presence of Jacobs' conditions in these dimensions through recent GHG inventories of the study cities. As Table 4 demonstrates, agreement is observed with our proposed metrics of Jacobs' conditions and the GHG performance of these cities.

An examination of infrastructure shows that eras of growth, technological choices, and policy/market forces can influence the extent to which a city exhibits carbon intensive infrastructure. For example, old buildings did not necessarily result in Lyon having high building sector GHGs per capita. However despite its tendency towards lowrise, dense construction in the old city, more sprawling development along its periphery pushed its transportation emissions higher. In the end, a city like Lyon can still have relatively low overall GHG emissions while maintaining eyes on the street (pedestrians), mixture of building ages, and short blocks.

With respect to climate, research suggests cities that experience more extreme conditions may have to contend with a stronger tendency towards passenger vehicles over public/active transportation. However, Singapore's policies of restricting automobile mode share demonstrate an approach that cities can use to overcome this, and low transportation-related emissions can result.

Furthermore, the relationship between Jacobs' conditions and low-carbon cities is not straightforward and presents many non-linearities. For instance, building shorter blocks may encourage walking and deter auto use, and thanks to this increase in walking, it can also support new commercial activity (contributing to Jacobs' mixed land-use condition); however, creating shorter blocks may increase vehicle idling, spur energy demand in others sectors of the economy, as well as boost VKT as the availability of roadways increases. To improve the carbon outcomes, transportation planners should focus on greater pathway density for active modes of transportation, rather than road density. Further, Kolkata, which exhibits Jacobs' conditions under the metrics assessed here as well as low levels of GHG emissions, will be challenged to maintain these as its infrastructure expands along with its economy. Overall, current development in emerging economies, such as Kolkata, will undoubtedly also lead to an increase in energy 
Please Cite as: Mohareb, E., Derrible, S., and Peiravian, F. (2015). "Intersections of Jane Jacobs' Conditions for Diversity and Low-Carbon Urban Systems: A Look at Four Global Cities." J. Urban Plann. Dev. , 10.1061/(ASCE)UP.1943-5444.0000287 , 05015004.

consumption, and in the absence of low-carbon energy adoption, higher per capita GHG emissions. Development that considers Jacobs' conditions can mitigate some of the longterm growth in GHGs, though reducing energy intensity of urban form. 
Please Cite as: Mohareb, E., Derrible, S., and Peiravian, F. (2015). "Intersections of Jane Jacobs' Conditions for Diversity and Low-Carbon Urban Systems: A Look at Four Global Cities." J. Urban Plann. Dev. , 10.1061/(ASCE)UP.1943-5444.0000287 , 05015004.

\section{References}

Annuaire Mairie, 2015. L'evolution du nombre d'inhabitants de Lyon. [Online] Available at: http://www.annuaire-mairie.fr/statistique-lyon.html, Accessed January 25, 2015.

Banerjee A., \& Das, S., 2006. Population, environment and development - Some issues in sustainability of Indian mega-cities Delhi and Kolkata. Presented at the European Population Conference, June 21-24, 2006, Liverpool, UK.

Bardhan, R.H., Kurisu, K., \& Hanaki, K., 2011. Linking urban form and quality of life in Kolkata, India. Presented at the 47th ISOCARP Congress 2011, Wuhan, China. [Online] Available at: http://www.isocarp.net/data/case_studies/1923.pdf, Accessed January 25, 2015.

Barr, L., 2000. "Testing for the Significance of Induced Highway Travel Demand in Metropolitan Areas." Transportation Research Record: Journal of the Transportation Research Board, 1706(-1), 1-8.

Baur, A. H., Thess, M., Kleinschmit, B., and Creutzig, F., 2014. "Urban Climate Change Mitigation in Europe: Looking at and beyond the Role of Population Density." Journal of Urban Planning and Development, 140(1), 04013003.

Bechle, M., Millet, C., \& Marshall, J., 2011. Effects of Income and Urban Form on Urban NO2: Global Evidence from Satellites. Environmental Science \& Technology, 45(11), 4914-4919.

Bergström, A, and Magnusson, R., 2003. "Potential of transferring car trips to bicycle during winter." Transportation Research Part A: Policy and Practice, 37(8), 649-666.

Bhandari, K., Parida, P., and Singh, P., 2013. "Estimation of Carbon Footprint of Fuel Loss Due to Idling of Vehicles at Signalised Intersection in Delhi." Procedia - Social and Behavioral Sciences, Elsevier B.V., 104, 1168-1177.

Bhatta, B., 2009. Analysis of urban growth pattern using remote sensing and GIS: a case study of Kolkata, India. International Journal of Remote Sensing, 30(18), 4733-4746.

Bhattacharya, B., 2007. Calcutta. Encyclopedia of Western Colonialism Since 1450. Macmillan Reference, USA, P.174. 
Please Cite as: Mohareb, E., Derrible, S., and Peiravian, F. (2015). "Intersections of Jane Jacobs' Conditions for Diversity and Low-Carbon Urban Systems: A Look at Four Global Cities." J. Urban Plann. Dev. , 10.1061/(ASCE)UP.1943-5444.0000287 , 05015004.

Breheny, M., 1996. Centrists, Decentrists and Compromisers - Views on the Future of Urban Form. In “The Compact City - a Sustainable Urban Form?” Jenks, M., Burton, E., and Williams, K., eds., Spon Press, Oxford.

Brookings Institution, 2012. Global Metro Monitor. [Online] Available: http://www.brookings.edu/research/interactives/global-metro-monitor-3, Accessed May 9, 2014.

Burchfield, M., Overman, H.G., Puga, D., \& Turner, M.A., 2006. Causes of sprawl: A portrait from space. Quarterly Journal of Economics, 121(2), 587-633.

CARMA, 2015. CARMA - Carbon monitoring for action. [Online] Available: http://carma.org/. Accessed January 25, 2015.

Census of India, 2011. Provisional Population Totals for West Bengal. [Online] Available: http://www.censusindia.gov.in/, Accessed January 25, 2015.

Cervero, R., 2003. "Road Expansion, Urban Growth, and Induced Travel: A Path Analysis." Journal of the American Planning Association, 69(2), 145-163.

Cervero, R., and Murakami, J., 2010. "Effects of built environments on vehicle miles traveled: evidence from 370 US urbanized areas." Environment and Planning A, 42(2), $400-418$.

Chavez, A., \& Ramaswami, A., 2013. Articulating a trans-boundary infrastructure supply chain greenhouse gas emission footprint for cities: Mathematical relationships and policy relevance. Energy Policy, 54, 376-384.

Chen, L., \& Ng, E., 2012. Outdoor thermal comfort and outdoor activities: A review of research in the past decade. Cities, 29, 118-125.

Chou, S.K., \& Ho, J.C., 1985. A National Strategy for Energy Management in Singapore. Energy, 10(9), 1017-1022.

CMAP, 2010. Chicago Regional Household Travel Inventory: Mode Choice and Trip Purpose for the 2008 and 1990 Surveys. Chicago Metropolitan Agency for Planning. Available at: http://www.cmap.illinois.gov/documents/10180/77659/TravelTracker_ModeShareReport 20100604.pdf/a67bf419-c05a-45c2-a127-a18d7984cd7d, Accessed January 25, 2015.

CMAP, 2012. Chicago 2010 Regional Greenhouse Gas Emissions Inventory. Chicago Metropolitan Agency for Planning. Available at: 
Please Cite as: Mohareb, E., Derrible, S., and Peiravian, F. (2015). "Intersections of Jane Jacobs' Conditions for Diversity and Low-Carbon Urban Systems: A Look at Four Global Cities." J. Urban Plann. Dev. , 10.1061/(ASCE)UP.1943-5444.0000287 , 05015004.

http://www.cmap.illinois.gov/documents/10180/27573/Chicago_2010_Regional_Greenh ouse_Gas_Emissions_Inventory_05-22-12.pdf/adf2a647-246e-48e0-aead-2766fa3281e8, Accessed January 25, 2015.

Codoban, N., and Kennedy, C., 2008. Metabolism of Neighborhoods. Journal of Urban Planning and Development, 134(1), 21-31

Conseil-General, 2015. Conseil Général du Département du Rhône (69). Available at: http://www.conseil-general.com/departements/conseils-generaux/conseil-general-rhonedepartement-69.htm, Accessed January 25, 2015

Cox, W., 2012. The Evolving Urban Form - Kolkata: The 50 Mile City. [Online] Available at: http://www.newgeography.com/content/002620-the-evolving-urban-formkolkata-50-mile-city, Accessed January 25, 2015.

Datta, P., 2012. Planning the City: Urbanisation and Reform in Calcutta c 1800-1940. Delhi, Tulika Books.

Davis, C., and Schaub, T., 2005. "A transboundary study of urban sprawl in the Pacific Coast region of North America: The benefits of multiple measurement methods." International Journal of Applied Earth Observation and Geoinformation, 7(4), 268-283.

Debnath, A.K., Mazharul Haque, M., Chin, H.C., and B., Yuen, 2011. Sustainable urban transport: Smart technology initiatives in Singapore. Transportation Research Record, 2243(1), 38-45.

Demographia, 2006. United Sates Central Business Districts - 50 largest urban areas 2000 data on employment and work trips. [Online] Available at: http://www.demographia.com/db-cbd2000.pdf, Accessed January 25, 2015.

Department of Energy and Climate Change, 2013. United Kingdom housing energy fact file, 2013. [Online] Available at: https://www.gov.uk/government/statistics/unitedkingdom-housing-energy-fact-file-2013, Accessed January 25, 2015.

EDB, 2015. Our History: The Sixties. Economic Development Board of Singapore. Available at: http://www.edb.gov.sg/content/edb/en/why-singapore/about-singapore/ourhistory/1960s.html, Accessed January 25, 2015.

Ewing, R., \& Cervero, R., 2010. Travel and the Built Environment. Journal of the American Planning Association, 76(3), 265-294. 
Please Cite as: Mohareb, E., Derrible, S., and Peiravian, F. (2015). "Intersections of Jane Jacobs' Conditions for Diversity and Low-Carbon Urban Systems: A Look at Four Global Cities." J. Urban Plann. Dev. , 10.1061/(ASCE)UP.1943-5444.0000287 , 05015004.

Ewing, R., Greenwald, M.J., Zhang, M., Bogaerts, M., \& Greene, W., 2013. Predicting Transportation Outcomes for LEED Projects. Journal of Planning Education and Research, 33(3) 265-279..

Foltete, J.C. \& Piombini, A., 2007. Urban layout, landscape uses and pedestrian usage. Landscape and Urban Planning, 81, 225-234.

Glaeser, E., \& Kohlhase, J., 2003. Cities, regions and the decline of transport costs. Papers in Regional Science, 83(1), 197-228.

Governance Knowledge Centre, 2008. Kolkata Municipal Corporation Case Study. [Online] Available at: http://indiagovernance.gov.in/bestpractices.php?id=39, Accessed January 25, 2015.

Grand Lyon, 2009a. Lyon, economic strength. Available at: http://www.business.greaterlyon.com/fileadmin/user_upload/fichiers/site_eco/200905_op ale_economie_indicateurs_aul_en.pdf, Accessed January 25, 2015.

Grand Lyon, 2009b. Plan Climat Grand Lyon. Available at: http://blogs.grandlyon.com/plan-climat/files/downloads/2010/09/23240227-DiagnosticClimat-synthetique.pdf, Accessed January 25, 2015.

Grant, J., 2002. Mixed Use in Theory and Practice - Canadian Experience with Implementing a Planning Principle. Journal of the American Planning Association, 68(1), 71-84.

HDB, 2014. Our Role. Housing \& Development Board. Available at: www.hdb.gov.sg/fi10/fi10320p.nsf/w/AboutUsOurRole, Accessed January 25, 2015.

ICLEI, 2009. Energy and Carbon Emissions Profiles of 54 South Asian Cities. [Online] Available:

http://southasia.iclei.org/fileadmin/user_upload/documents/Energy_and_Carbon_Emissio ns_Profiles_for_54_South_Asian_Cities.pdf, Accessed Jan 23, 2015.

IEA, 2008. World Energy Outlook - 2008. OECD/IEA 2008, Paris.

IGPA, 1973. Chicago since 1840 - A time-series handbook. [Online] Available: http://skogan.org/files/Chicago_Since_1840_-_A_Time_Series_Data_Handbook2.pdf, Accessed January 25, 2015. 
Please Cite as: Mohareb, E., Derrible, S., and Peiravian, F. (2015). "Intersections of Jane Jacobs' Conditions for Diversity and Low-Carbon Urban Systems: A Look at Four Global Cities." J. Urban Plann. Dev. , 10.1061/(ASCE)UP.1943-5444.0000287 , 05015004.

INSEE, 2015, Unités urbaines de plus de 100000 habitants en 2011, Available at: http://www.insee.fr/fr/themes/tableau.asp?reg_id=0\&id=201, Accessed January 31, 2015

Intergovernmental Panel on Climate Change, 2014. Chapter 12: Human Settlements, Infrastructure and Spatial Planning. Fifth Assessment Report, Working Group 3, see Figure 12.14, p. 40. [Online] Available: https://www.ipcc.ch/report/ar5/wg3/ Accessed June 17, 2014.

Jabareen, Y.R, 2006. Sustainable urban form - Their typologies, models, and concepts. Journal of Planning Education and Research, 26, 38-52.

Jacobs, J., 1961. The Death and Life of Great American Cities. Random House, New York, NY.

Johansson, E., \& Emmanuel, R., 2006. The influence of urban design on outdoor thermal comfort in the hot, humid city of Colombo, Sri Lanka. International Journal of Biometeorology, 51, 119-133.

Kennedy, C., Steinberger, J., Gasson, B., Hanson, Y., Hillman, T., Havranek, M., Pataki, D., Phdungsilp, A., \& Ramaswami, A., 2009. Greenhouse gas emissions from global cities. Environmental Science \& Technology, 43, 7297-7302.

Kennedy, C., 2011. The Evolution of Great World Cities: Urban Wealth and Economic Growth. University of Toronto Press, Toronto, ON.

King, K., 2013. Jane Jacobs and "The Need for Aged Buildings" - Neighbourhood Historical Development Pace and Community Social Relations. Urban Studies, Published online March 4, 2013.

Ko, Y., 2013. "Urban Form and Residential Energy Use: A Review of Design Principles and Research Findings." Journal of Planning Literature, 28(4), 327-351.

Kundu, N., 2003. Urban slum reports - the case of Kolkata, India. [Online] Available at: http://www.ucl.ac.uk/dpu-projects/Global_Report/pdfs/Kolkata.pdf, accessed May 12, 2014.

Lapinskienė, G., Tvaronavičienè, M., and Vaitkus, P., 2014. "Greenhouse gases emissions and economic growth - evidence substantiating the presence of environmental Kuznets curve in the EU." Technological and Economic Development of Economy, 20(1), $65-78$. 
Please Cite as: Mohareb, E., Derrible, S., and Peiravian, F. (2015). "Intersections of Jane Jacobs' Conditions for Diversity and Low-Carbon Urban Systems: A Look at Four Global Cities." J. Urban Plann. Dev. , 10.1061/(ASCE)UP.1943-5444.0000287 , 05015004.

Litman, T., 2014. Well measured - developing indicators for sustainable and livable transport planning. Victoria Transport Policy Institute. [Online] Available at: http://www.vtpi.org/wellmeas.pdf, accessed May 12, 2014.

Long, C., 2002. "A history of urban planning policy and heritage protection in Vientiane, Laos." International Development Planning Review, 24(2), 127-144.

Lotfi, S., and Koohsari, M. J., 2011. "Neighborhood Walkability in a City within a Developing Country." (December), 402-408.

LTA, 2011. Passenger Transport Mode Shares in World Cities. Land Transport Authority. Available at: http://taacademy.gov.sg/doc/J11Novp60PassengerTransportModeSHares.pdf, accessed June 1, 2013.

Mashayekh, Y., Asce, H. M., Hendrickson, C. T., Matthews, H. S., and Asce, A. M. (2014). "LEED-Certified Residential Brownfield Development as a Travel and Greenhouse Gas Emission Reduction Strategy." Journal of Urban Planning and Development, Available , 1-8.

McClendon, D., 2013. Chicago Growth 1850-1990. University of Illinois at Chicago. Available at: http://tigger.uic.edu/depts/ahaa/imagebase/chimaps/, accessed May 28, 2013.

Mills, E.S., 2001. Chap 11: Evolution of the Chicago Landscape: Population Dynamics, Economic Development, and Land Use Change. In Growing Populations, Changing Landscapes: Studies from India, China, and the United States. Edited by Indian National Science Academy, Chinese Academy of Science, National Academy of Sciences (U.S.). National Academy Press, Washington, DC.

Miranda-Moreno, L.F. \& Lahti, A.C., 2013. Temporal trends and the effect of weather on pedestrian volumes - A case study of Montreal, Canada. Transportation Research D, 22, 54-59.

Mohareb, E. A., and Kennedy, C. A., 2014. "Scenarios of technology adoption towards low-carbon cities." Energy Policy, Elsevier, 66, 685-693.

Nankervis, M., 1999. The effect of weather and climate on bicycle commuting. Transportation Research A, 33, 417-431.

NEA, 2010. Singapore's Second National Communication: Under the United Nations Framework Convention on Climate Change. Singapore National Environment Agency. Available at: http://app.mewr.gov.sg/data/imgCont/1439/singapore_snc2010.pdf, accessed July 16, 2013 
Please Cite as: Mohareb, E., Derrible, S., and Peiravian, F. (2015). "Intersections of Jane Jacobs' Conditions for Diversity and Low-Carbon Urban Systems: A Look at Four Global Cities." J. Urban Plann. Dev. , 10.1061/(ASCE)UP.1943-5444.0000287 , 05015004.

Newman, P.W.G., \& Kenworty, J.R., 1989. Gasoline Consumption and Cities. Journal of the American Planning Association, 55(1), 24-37.

Noland, R. B., 2001. "Relationships between highway capacity and induced vehicle travel." Transportation Research Part A: Policy and Practice, 35(1), 47-72.

Norman, J., MacLean, H.L., \& Kennedy, C.A., 2006. Comparing high and low residential density: life cycle analysis of energy use and greenhouse gas emissions. Journal of Urban Planning and Development, 132(1), 10-21.

Nowak, D. J., and Greenfield, E. J., 2012. "Tree and impervious cover change in U.S. cities.” Urban Forestry \& Urban Greening, Elsevier GmbH., 11(1), 21-30.

Ng, M.K., \& P. Hills, 2003. "World cities or great cities? A comparative study of five Asian metropolises". Cities, 20(3), 151-165.

NTPD, 2013. A Sustainable Population for a Dynamic Singapore: Population White Paper. National Population and Talent Division (Singapore Government). Available at: http://202.157.171.46/whitepaper/downloads/population-white-paper.pdf, accessed July 8, 2013

OEE, 2012. Comprehensive Energy Use Database, 1990-2010. Office of Energy Efficiency. Available at: http://oee.nrcan.gc.ca, accessed July 21, 2013

Olszewski, P. S., 2007. "Singapore motorisation restraint and its implications on travel behaviour and urban sustainability." Transportation, 34(3), 319-335.

Otkay, D., 2012. Human sustainable urbanism: In pursuit of ecological and socialcultural sustainability. Procedia Social and Behavioral Sciences, 36, 16-27.

Pelletier, A., Rossiaud, J., Bayard, F., \& P. Cayez, 2007. Histoire de Lyon: Des origines à nos jours. Editions Lyonnaises d'Art et d'Histoire, Lyon, France.

Populstat, 2013. Singapore - Historical demographical data of whole country. [Online] Available at: http://www.populstat.info/Asia/singapoc.htm, Accessed July 7, 2013

Porter, C., 2009. Greenhouse Gas Benefits of Land Use Strategies. Transportation, Land Use, Planning, and Air Quality: Selected Papers of the Transportation, Land Use, Planning, and Air Quality Conference 2009, Denver, Colorado, United States July 28-29, 2009. pp. 141-150. 
Please Cite as: Mohareb, E., Derrible, S., and Peiravian, F. (2015). "Intersections of Jane Jacobs' Conditions for Diversity and Low-Carbon Urban Systems: A Look at Four Global Cities." J. Urban Plann. Dev. , 10.1061/(ASCE)UP.1943-5444.0000287 , 05015004.

Quah, A. K. L., and Roth, M., 2012. "Diurnal and weekly variation of anthropogenic heat emissions in a tropical city, Singapore." Atmospheric Environment, Elsevier Ltd, 46, 92103.

Ramaswami, A., and Chavez, A., 2013. "What metrics best reflect the energy and carbon intensity of cities? Insights from theory and modeling of 20 US cities." Environmental Research Letters, 8(3), 035011.

Rizwan, A. M., Dennis, Y. C. L., and Liu, C. H., 2008. "A review on the generation, determination and mitigation of Urban Heat Island." Journal of Environmental SciencesChina, 20(1), 120-128.

Santos, G., Behrendt, H., and Teytelboym, A. (2010). "Part II: Policy instruments for sustainable road transport." Research in Transportation Economics, Elsevier Ltd, 28(1), 46-91.

Schafer, A., \& D.G. Victor, 2000. The future mobility of the world population. Transportation Research Part A, 34, 171-205

Seto, K. C., Dhakal, S., Bigio, A., Blanco, H., Delgado, G. C., Dewar, D., Huang, L., Inaba, A., Kansal, A., Lwasa, S., McMahon, J. E., Muller, D. B., Murakami, J., Nagendra, H., and Ramaswami, A. (2014). "Chapter 12: Human Settlements, Infrastructure and Spatial Planning." Climate Change 2014: Mitigation of Climate Change. Contribution of Working Group III to the Fifth Assessment Report of the Intergovernmental Panel on Climate Change, O. Edenhofer, R. Pichs-Madruga, Y. Sokona, E. Farahani, S. Kadner, K. Seyboth, A. Adler, I. Baum, S. Brunner, P. Eickemeier, B. Kriemann, J. Savolainen, S. Schlömer, C. von Stechow, T. Zwickel, and J. C. Minx, eds., Cambridge University Press, Cambridge, UK.

SingStat, 2011. Census of Population 2010 Statistical Release 2: Households and Housing. Department of Statistics, Ministry of Trade \& Industry. Singapore: Singapore.

Sivak, M., 2013. Air conditioning versus heating: climate control is more energy demanding in Minneapolis than in Miami. Environmental Research Letters, 8, 1-4.

Su, Q. (2010). "Travel demand in the US urban areas: A system dynamic panel data approach." Transportation Research Part A: Policy and Practice, Elsevier Ltd, 44(2), $110-117$.

Talen, E., 2011. Sprawl Retrofit - Sustainable Urban Form in Unsustainable Places. Environment and Planning B: Planning and Design, 38, 952-978. 
Please Cite as: Mohareb, E., Derrible, S., and Peiravian, F. (2015). "Intersections of Jane Jacobs' Conditions for Diversity and Low-Carbon Urban Systems: A Look at Four Global Cities." J. Urban Plann. Dev. , 10.1061/(ASCE)UP.1943-5444.0000287 , 05015004.

Taleb, N., 2012, Antifragile: Things That Gain from Disorder, Random House, New York, NY.

UrbaLyon, 2011. Observatoire Partenarial Démographie n4 - Grand Lyon: Chiffres clés 2008. Available at: http://www.urbalyon.org/Document/Observatoire_Partenarial_Demographie_n_4_-_Grand_Lyon_Chiffres_cles__2008_-3147, Accessed January 25, 2015.

URA, 2015. Master Plan 2014, Urban Redevelopment Authority. Available at: http://www.ura.gov.sg/uol/master-plan.aspx?p1=View-Master-Plan\&p2=Master-Plan2014, Accessed January 25, 2015.

US Census, 2013. State and County Quick Facts. [Online] Available at: http://quickfacts.census.gov/qfd/index.html, accessed April 29, 2013.

Wiedenhofer, D., Lenzen, M., and Steinberger, J. K., 2013. "Energy requirements of consumption: Urban form, climatic and socio-economic factors, rebounds and their policy implications.” Energy Policy, Elsevier, 63, 696-707.

World Bank, 2013. Singapore. Data Catalogue. Available at: http://data.worldbank.org/country/singapore, accessed May 26, 2013.

World Bank, 2015a. GDP per Capita (Current US). [Online] Available at: http://data.worldbank.org/indicator/NY.GDP.PCAP.CD, Accessed Jan 23, 2015.

World Bank, 2015b. Motor Vehicles (per 1000 people). [Online] Available at: http://data.worldbank.org/indicator/IS.VEH.NVEH.P3, Accessed Jan 23, 2015.

Yuen, B., 2005. Romancing the high-rise in Singapore. Cities, 22(1), 3-13.

Yew, L.K., 2000. From Third World to First: The Singapore Story: 1965-2000. HarperCollins, New York, NY.

Yin, L. 2013. "Assessing Walkability in the City of Buffalo: Application of Agent-Based Simulation.” (September), 166-175. 